\section{Michigan Technological \begin{tabular}{lll}
\hline 1 8 8 & University \\
\hline
\end{tabular}}

Michigan Technological University Digital Commons @ Michigan Tech

$10-24-2006$

\title{
Atmospheric chemistry of a 33-34 hour old volcanic cloud from Hekla Volcano (Iceland): Insights from direct sampling and the application of chemical box modeling
}

\author{
William I. Rose \\ Michigan Technological University \\ Genevieve A. Millard \\ University of Cambridge \\ Tamsin A. Mather \\ University of Cambridge \\ Donald E. Hunton \\ Air Force Research Laboratory \\ Bruce Anderson \\ NASA Langley Research Center Hampton \\ Follow this and additional works at: https://digitalcommons.mtu.edu/geo-fp \\ Part of the for additional authors
}

\section{Recommended Citation}

Rose, W. I., Millard, G. A., Mather, T. A., Hunton, D. E., Anderson, B., Oppenheimer, C., Thornton, B. F., Gerlach, T. M., Viggiano, A. A., Kondo, Y., Miller, T. M., \& Ballenthin, J. O. (2006). Atmospheric chemistry of a 33-34 hour old volcanic cloud from Hekla Volcano (Iceland): Insights from direct sampling and the application of chemical box modeling. Journal of Geophysical Research, 111(D20). http://dx.doi.org/ 10.1029/2005JD006872

Retrieved from: https://digitalcommons.mtu.edu/geo-fp/40

Follow this and additional works at: https://digitalcommons.mtu.edu/geo-fp

Part of the Geology Commons, Mining Engineering Commons, and the Other Engineering Commons 


\section{Authors}

William I. Rose, Genevieve A. Millard, Tamsin A. Mather, Donald E. Hunton, Bruce Anderson, Clive Oppenheimer, Brett F. Thornton, Terrence M. Gerlach, Albert A. Viggiano, Yutaka Kondo, Thomas M. Miller, and John O. Ballenthin 


\title{
Atmospheric chemistry of a 33-34 hour old volcanic cloud from Hekla Volcano (Iceland): Insights from direct sampling and the application of chemical box modeling
}

\author{
William I. Rose, ${ }^{1}$ Genevieve A. Millard, ${ }^{2}$ Tamsin A. Mather, ${ }^{2,3}$ Donald E. Hunton, ${ }^{4}$ \\ Bruce Anderson, ${ }^{5}$ Clive Oppenheimer, ${ }^{6}$ Brett F. Thornton, ${ }^{7}$ Terrence M. Gerlach, ${ }^{8}$ \\ Albert A. Viggiano, ${ }^{4}$ Yutaka Kondo, ${ }^{9}$ Thomas M. Miller, ${ }^{4}$ and John O. Ballenthin ${ }^{4}$ \\ Received 10 November 2005; revised 23 February 2006; accepted 5 July 2006; published 24 October 2006.
}

[1] On 28 February 2000, a volcanic cloud from Hekla volcano, Iceland, was serendipitously sampled by a DC-8 research aircraft during the SAGE III Ozone Loss and Validation Experiment (SOLVE I). It was encountered at night at $10.4 \mathrm{~km}$ above sea level (in the lower stratosphere) and 33-34 hours after emission. The cloud is readily identified by abundant $\mathrm{SO}_{2}(\leq 1 \mathrm{ppmv}), \mathrm{HCl}(\leq 70 \mathrm{ppbv}), \mathrm{HF}(\leq 60 \mathrm{ppbv})$, and particles (which may have included fine silicate ash). We compare observed and modeled cloud compositions to understand its chemical evolution. Abundances of sulfur and halogen species indicate some oxidation of sulfur gases but limited scavenging and removal of halides. Chemical modeling suggests that cloud concentrations of water vapor and nitric acid promoted polar stratospheric cloud (PSC) formation at 201-203 K, yielding ice, nitric acid trihydrate (NAT), sulfuric acid tetrahydrate (SAT), and liquid ternary solution $\mathrm{H}_{2} \mathrm{SO}_{4} / \mathrm{H}_{2} \mathrm{O} / \mathrm{HNO}_{3}$ (STS) particles. We show that these volcanically induced PSCs, especially the ice and NAT particles, activated volcanogenic halogens in the cloud producing $>2 \mathrm{ppbv} \mathrm{ClO}_{\mathrm{x}}$. This would have destroyed ozone during an earlier period of daylight, consistent with the very low levels of ozone observed. This combination of volcanogenic PSCs and chlorine destroyed ozone at much faster rates than other PSCs that Arctic winter. Elevated levels of $\mathrm{HNO}_{3}$ and $\mathrm{NO}_{\mathrm{y}}$ in the cloud can be explained by atmospheric nitrogen fixation in the eruption column due to high temperatures and/or volcanic lightning. However, observed elevated levels of $\mathrm{HO}_{x}$ remain unexplained given that the cloud was sampled at night.

Citation: Rose, W. I., et al. (2006), Atmospheric chemistry of a 33-34 hour old volcanic cloud from Hekla Volcano (Iceland): Insights from direct sampling and the application of chemical box modeling, J. Geophys. Res., 111, D20206, doi:10.1029/2005JD006872.

\section{Introduction}

[2] The 2000 eruption of Hekla volcano began at about 1815 UT on 26 February, with a brief (1-2 hours long)

\footnotetext{
${ }^{1}$ Geological Engineering and Sciences, Michigan Technological University, Houghton, Michigan, USA.

${ }^{2}$ Department of Earth Sciences, University of Cambridge, Cambridge, $\mathrm{UK}$.

${ }^{3}$ Now at Department of Earth Sciences, University of Oxford, Oxford, $\mathrm{UK}$.

${ }^{4}$ Air Force Research Laboratory, Hanscom Air Force Base, Massachusetts, USA.

${ }^{5}$ NASA Langley Research Center Hampton, Virginia, USA.

${ }^{6}$ Department of Geography, University of Cambridge, Cambridge, UK.

${ }^{7}$ Program in Atmospheric and Oceanic Sciences, University of Colorado, Boulder, Colorado, USA.

${ }^{8}$ U.S. Geological Survey Cascades Volcano Observatory, Vancouver, Washington, USA.

${ }^{9}$ Research Center for Advanced Science and Technology, University of Tokyo, Tokyo, Japan.

Copyright 2006 by the American Geophysical Union. 0148-0227/06/2005JD006872
}

explosive phase generating a volcanic cloud reaching 10 $12 \mathrm{~km}$ above sea level. During its first few hours, this volcanic cloud drifted with the wind to the NNE, and produced an ash fall blanket with an estimated bulk volume of $0.01 \mathrm{~km}^{3}$ [Haraldsson, 2002]. Snowfall associated with the volcanic cloud in Iceland scavenged $\mathrm{SO}_{4}^{2-}, \mathrm{Cl}^{-}$, and $\mathrm{F}^{-}$ [Moune et al., 2006]. The eruption then became effusive in character with about $0.18 \mathrm{~km}^{3}$ of lava emitted from a fissure over the next 11 days. The total mass of the initial tephra fall deposit and lava flows was estimated as $4.14 \times 10^{11} \mathrm{~kg}$ [Sharma et al., 2004]. The explosive phase of the eruption was detected by many satellite sensors, which showed that the cloud was $\mathrm{SO}_{2}$-rich and its particles were predominately composed of ice [Rose et al., 2003]. Ground-based meteorological radar observations imaged the eruption volcanic cloud for 7-10 hours, i.e., up to 9 hours after the end of the eruption. The radar signals are consistent with ice nucleation and growth persisting for several hours after the explosive phase stopped, the volcanic cloud continued to produce radar reflections even after fallout of coarse ice and ash [Lacasse et al., 2003]. After the explosive phase the 
ice-rich volcanic cloud drifted northward toward Svalbard for about 35 hours (see Figures $1 \mathrm{a}$ and $1 \mathrm{~b}$ ), while the mass of ice present in the cloud diminished from $>1 \mathrm{Tg}$ to less than $0.2 \mathrm{Tg}$. The initial $\mathrm{SO}_{2}$ mass in the cloud was estimated at $0.16-0.24 \mathrm{Tg}$ [Rose et al., 2003].

[3] Thirty-three to thirty-four hours after eruption (inferred because the aircraft encountered the younger portion of a cloud erupted from 35 to 33 hours before), at 05080518 UT on 28 February 2000 an atmospheric research DC-8 aircraft from NASA Dryden crossed the volcanic cloud at an altitude of $10.4 \mathrm{~km}$ at $76.4-75.7^{\circ} \mathrm{N}$ latitude and $9.0-4.4^{\circ} \mathrm{W}$ longitude (representing a distance traveled of about $100 \mathrm{~km}$; Figure 1a). Modeled trajectories for the volcanic cloud at various levels are shown in Figure 1b. The aircraft was instrumented to study polar stratospheric clouds as part of the SAGE III Ozone Loss and Validation Experiment (SOLVE/THESEO 2000 [Newman et al., 2002]) campaign, and most of the analytical equipment was in operation during the encounter. The temperature in the cloud was 201-203 K (Figure 2) and because of the time of year and latitude (before true dawn) there is not likely to have been any significant solar heating effects. In an earlier paper [Rose et al., 2003] we reported on the remote sensing and validations that came from the instruments on the NASA aircraft. In another study, Hunton et al. [2005] used part of the initial encounter SOLVE/THESEO 2000 data plus measurements collected from subsequent volcanic cloud encounters over the following 18 days to investigate the processes involved in formation of $\mathrm{H}_{2} \mathrm{SO}_{4}$ and other reactions. In this paper we investigate only the measurements from the first encounter, where the cloud is less diluted, with the aim to understand the early stages of chemical and physical evolution of a volcanogenic stratospheric cloud by combining the observations from the aircraft with a comprehensive stratospheric chemistry model along the volcanic cloud trajectory. As some of the aircraft results were used to initialize this model we will begin by discussing these measurements before describing the modeling methodology.

\section{Direct Measurements of the Hekla Volcanic Cloud}

[4] Table 1 shows a listing of data used in this paper from the NASA DC-8 during the SOLVE I mission. All were collected on 28 February 2000 at 0508 to 0518 UT, during the intersection of the aircraft with the drifting volcanic cloud. For this study, the data were obtained by downloading from the SOLVE web page where all data have been archived for more than four years. Estimates of errors in these data are not always available since the volcanic cloud had a somewhat unusual chemistry. References to articles that discuss errors are given in Table 1.

[5] $\mathrm{SO}_{2}, \mathrm{HCl}$, and $\mathrm{HF}$ mixing ratios were determined with the Chemical Ionization Mass Spectrometer (Figures $3 \mathrm{a}$ and $3 \mathrm{~b}$ ). All three species provide clear definitions of the cloud boundary, since all of these gases have low abundance in the ambient atmosphere. The mixing ratios of the three gases are strongly correlated and the mean mass ratio of $\mathrm{HCl} / \mathrm{HF}$ is 1.15 and $\mathrm{HCl} / \mathrm{SO}_{2}$ is 0.068 . These chemical signatures are consistent with volcanic gas composition as discussed below in section 3.2.

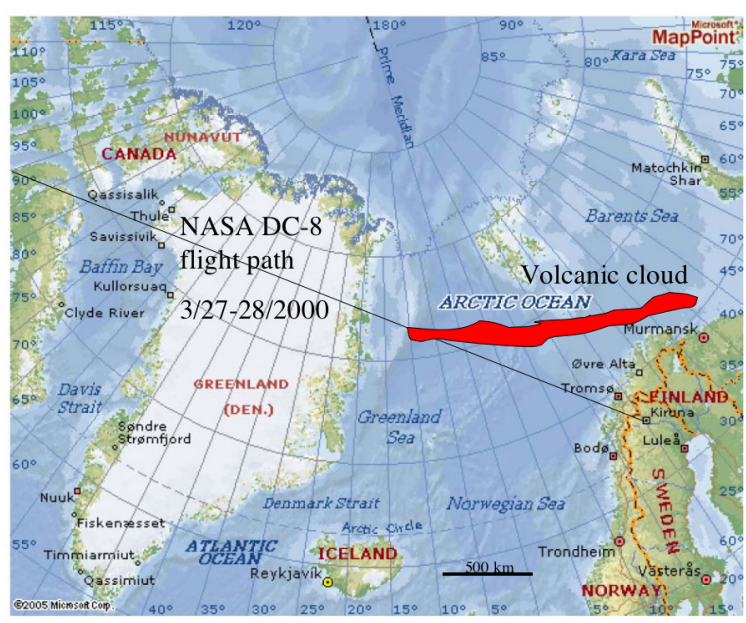

Figure 1a. Map showing the flight path of the NASA DC8 traveling from NASA Dryden to Kiruna, Sweden, on 26-28 February 2000. The position of the Hekla volcanic cloud at 1115 UT on 28 February 2000 based on MODIS imagery [Rose et al., 2003] is shown. The aircraft encountered the volcanic cloud at $0508-0518$ UT on 28 February.

[6] Several other gaseous components were enriched in the volcanic cloud compared with the background beyond the volcanic cloud margins (Figure 4), including $\mathrm{HNO}_{3}$, $\mathrm{NO}_{\mathrm{y}}, \mathrm{H}_{2} \mathrm{SO}_{4}, \mathrm{CO}$ and possibly $\mathrm{CO}_{2} . \mathrm{HNO}_{3}$ and $\mathrm{NO}_{\mathrm{y}}$ show highly correlated patterns $\left(\mathrm{NO}_{\mathrm{y}} / \mathrm{HNO}_{3}=\sim 3-4\right)$ with highest values $\left(\sim 4\right.$ ppbv $\mathrm{HNO}_{3}, \sim 12$ ppbv $\left.\mathrm{NO}_{\mathrm{y}}\right)$ on the north side of the volcanic cloud. $\mathrm{NO}_{\mathrm{y}}$ is a grab bag designation for reactive nitrogen compounds including $\mathrm{NO}, \mathrm{NO}_{2}$ (known collectively as $\mathrm{NO}_{\mathrm{x}}$ ) and all compounds that are products of atmospheric oxidation of $\mathrm{NO}_{\mathrm{x}}\left(\mathrm{HNO}_{3}, \mathrm{HONO}, \mathrm{NO}_{3}, \mathrm{~N}_{2} \mathrm{O}_{5}\right.$, $\mathrm{HNO}_{4}$ and a number of other species). Gas phase $\mathrm{H}_{2} \mathrm{SO}_{4}$ correlates with $\mathrm{SO}_{2}$ with a ratio of 1:3000, although most $\mathrm{H}_{2} \mathrm{SO}_{4}$ in the volcanic cloud is likely to be in particle form; both species are enriched on the north side of the cloud. $\mathrm{CO}$ has a minor ( 45 ppbv) enrichment, while $\mathrm{CO}_{2}$ is barely above background ( $\sim 1$ ppmv). $\mathrm{CO}$ is also more enriched on the north side of the cloud. Measurements of $\mathrm{OH}$ and $\mathrm{HO}_{2}$ show remarkable increases in the volcanic cloud (Figure 5), which we discuss more fully below. Ozone was strongly depleted inside the volcanic cloud especially on the north side, where it is almost altogether absent. $\mathrm{CH}_{4}$ and $\mathrm{NO}_{2}$ show some evidence for decreases in the volcanic cloud compared to the background ( $\sim 30 \mathrm{ppbv}$ for $\mathrm{CH}_{4} ; \sim 25 \mathrm{pptv}$ for $\mathrm{NO}_{2}$ ). Several other gases have mixing ratios indistinguishable from the air outside the volcanic cloud $\left(\mathrm{HCN}, \mathrm{NO}, \mathrm{N}_{2} \mathrm{O}\right)$. The temperatures measured during the cloud encounter ranged from 201 to $203 \mathrm{~K}$, while the pressures ranged from 216.3 to $216.9 \mathrm{hPa}$. We note that measurements may not reflect the volcanic cloud alone, but likely also reflect differences between stratospheric and tropospheric air during dynamic mixing (the volcanic cloud has entrained tropospheric air on its passage to the stratosphere). However, as we will discuss later (section 4.4), the mixing of tropospheric air into the stratosphere alone cannot account for the pronounced negative $\mathrm{O}_{3}$ anomaly within the volcanic cloud.

[7] Particle measurements also define the volcanic cloud well. There are SOLVE/THESEO 2000 data for two size ranges: $<2 \mu \mathrm{m}$ and $0.5-20 \mu \mathrm{m}$. Figure $6 \mathrm{a}$ shows the 


\section{NOAA HYSPLIT MODEL
Forward trajectories starting at 18 UTC 26 Feb 00 FNL Meteorological Data}

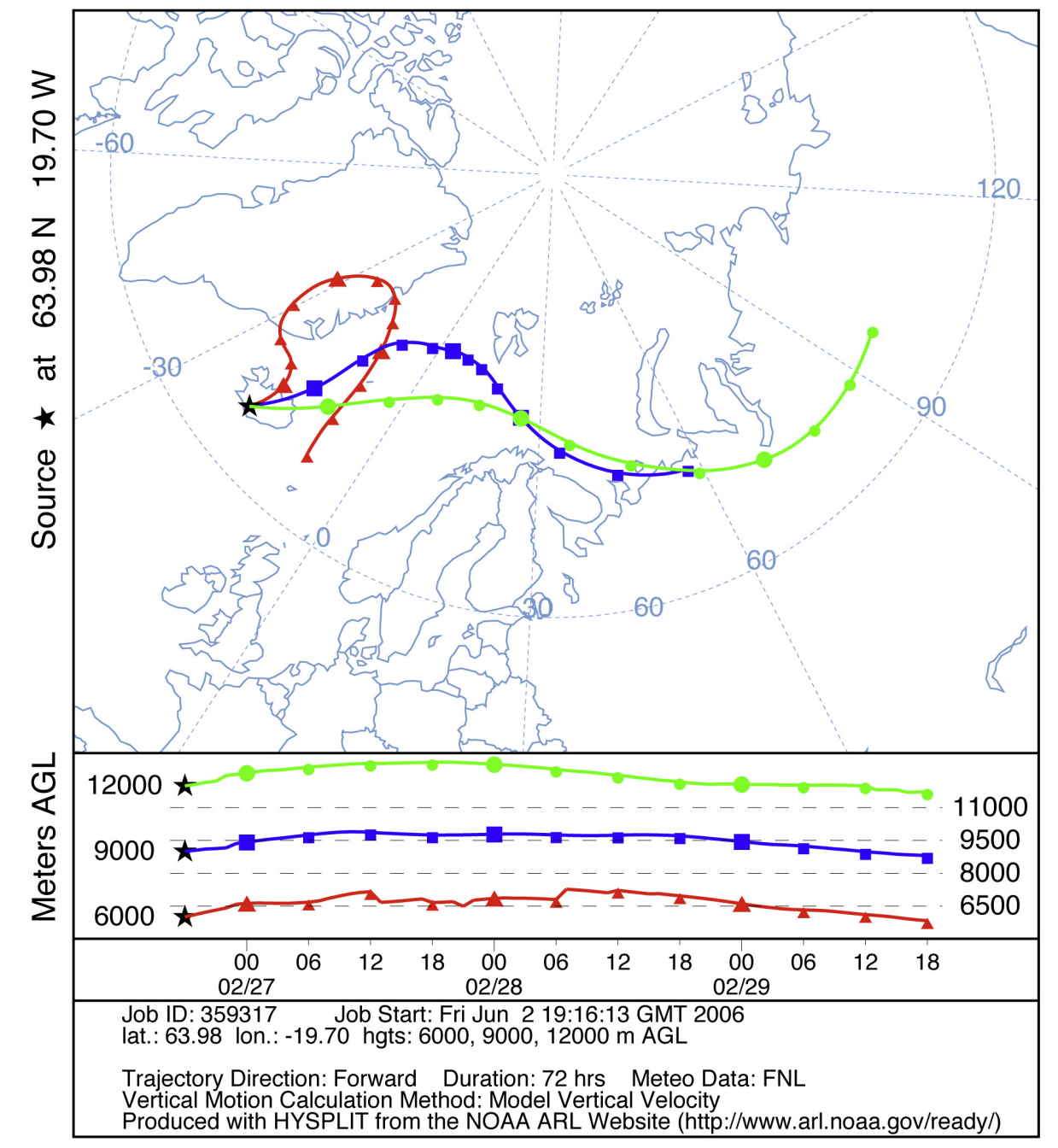

Figure 1b. NOAA Hysplit model results for forward trajectories of the Hekla Volcanic cloud, beginning above the volcano at 1800 UT on 26 February 2000, at elevations of 6000 (red), 9000 (blue), and $12,000 \mathrm{~m}$ (green) above sea level. Points are plotted every 6 hours. The blue line tracks closely to the positions determined by satellite data [Rose et al., 2003].

strikingly higher (fine particles from 4 to $2000 \mathrm{~nm}$ diameter) fine particle number densities detected within the Hekla volcanic cloud and reported by Hunton et al. [2005]. According to Hunton et al. [2005] a majority of non refractory aerosols can be volatilized with heating ("unheated" in Figure 6a represents the sum of volatile and non volatile aerosols) and these volatile aerosols likely represent ice, sulfate and nitric acid trihydrate (NAT) aerosols, while the "nonvolatile" ("heated" in Figure 6a) fraction ( 20$30 \%$ ) is made of non condensed matter and may be silicate ash. Hunton et al. [2005] reported a maximum total "aerosol" volume (4-2000 nm diameter) of $65 \mu^{3} \mathrm{~cm}^{-3}$, of which a significant fraction may be very fine ash. Hunton et al. [2005] also report peaks in the "aerosol" (4-2000 nm diameter) size distribution at $0.07 \mu \mathrm{m}$ and $0.36 \mu \mathrm{m}$. Little is known about ash this fine, but it seems likely that this fine material may have nucleated larger ice particles detected by remote sensing [Rose et al., 2003] and the FSSP-300 (Figure 6a).

[8] In this paper we have used data from the FSSP-300 probe, which provides a variety of information on particles in the diameter range of 0.42 and $20 \mu \mathrm{m}$. This size range only overlaps slightly with the aerosol size data discussed by Hunton et al. [2005]. As shown by Hallar et al. [2004] this instrument yields the particle size distribution and mass proportions of particles and also the surface area. Figures $6 \mathrm{~b}$ and $6 \mathrm{c}$ show striking particle size patterns of the volcanic cloud as defined by the FSSP-300. Figure $6 \mathrm{~b}$ shows particle size distributions within the Hekla cloud, and Figure 6c plots FSSP data showing how particle size and numbers 


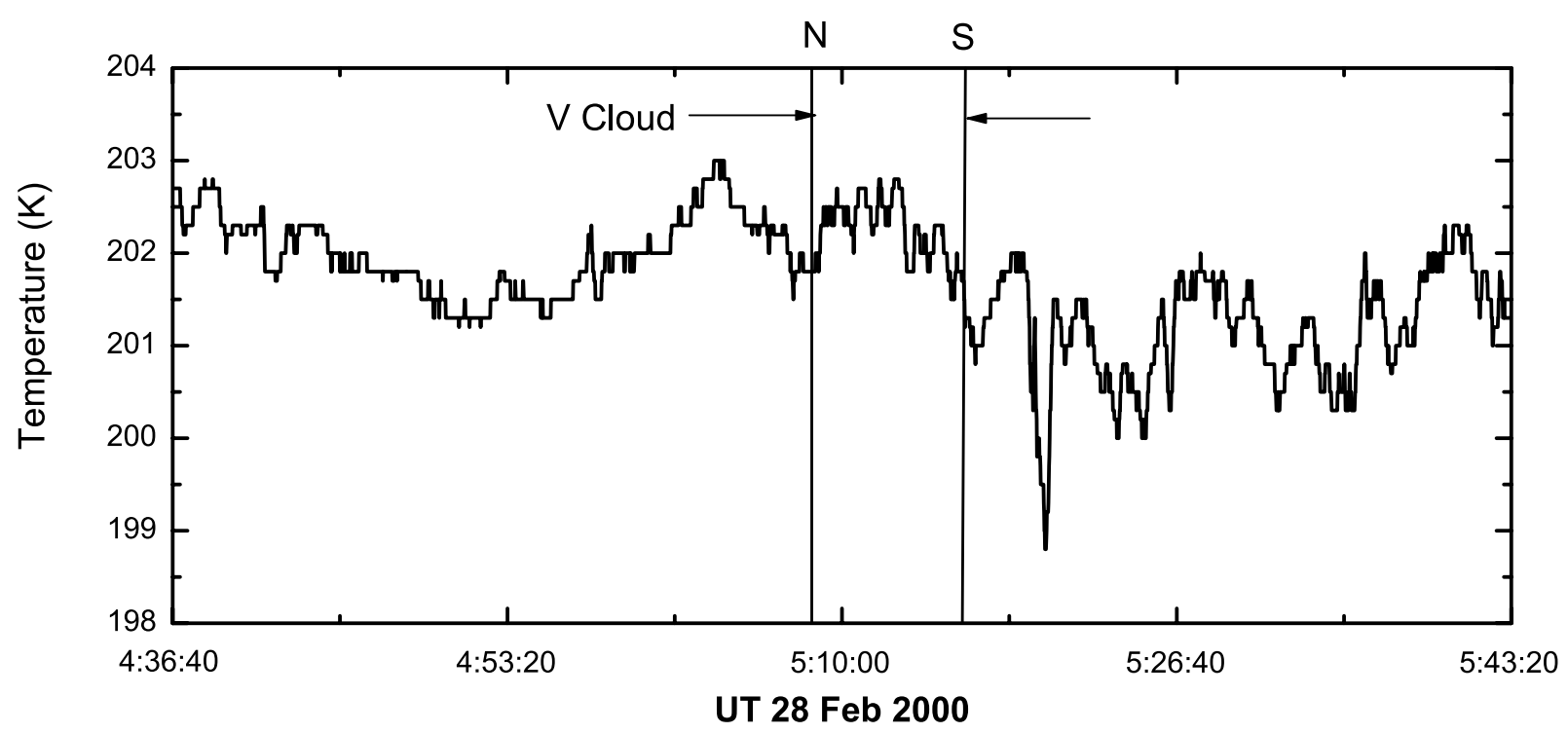

Figure 2. Plot showing the temperatures measured for the ambient atmosphere along the track of the NASA DC-8 (Figure 1a). Lines bound the volcanic cloud position.

differ across the cloud traverse. Particle numbers (here larger particles with diameters of 0.42 to $20 \mu \mathrm{m}$ ) are higher on the north side (above in Figure 6b; to the left in Figure 6c), while there is much more particle mass toward the south side of the cloud, where larger particles occur in smaller numbers. When used together with data from the JPL laser hygrometer (Figure 6d), it is possible to estimate the total cloud water content, including both water vapor and ice. Figure 6e gives the final results, showing that the surface area of particles is about 6-8 times higher on the south side of the volcanic cloud, where the larger particles are found, and that the highest masses of total cloud water, naturally coincides with these large particles. The total mass of water in ice is less than $1 \mathrm{mg} \mathrm{m}^{-3}$, a rather low value for a cirrus cloud. The FSSP may underestimate total cloud water, because it does not measure particles larger than $20 \mu \mathrm{m}$. This calculation is thoroughly discussed by Hallar et al. [2004].

\section{Modeling the Chemistry of the Volcanic Cloud}

[9] Previous atmospheric chemistry studies of volcanic source gases have focused on the emission of sulfur compounds [Bekki and Pyle, 1994; Bekki, 1995; Bekki et al.,
1996; Al-Saadi et al., 2001; Rozanov et al., 2002; Tie et al., 2003]. Halogen emissions from volcanoes have been measured widely in the troposphere [Symonds et al., 1988; Zreda-Gostynska et al., 1997; Bureau et al., 2000; Horrocks et al., 2003; Bobrowski et al., 2003; Delmelle, 2003; Aiuppa et al., 2005a]; however, the direct measurement of volcanically enhanced halogen gases at this altitude in an explosive eruption volcanic cloud is limited to these interceptions of Hekla's volcanic cloud by the DC-8 in 2000. Previous to this, it was uncertain if significant amounts of $\mathrm{HCl}$ would ever reach the stratosphere during a volcanic eruption due to uptake onto particles and rain out within the volcanic cloud [Tabazadeh and Turco, 1993; Textor et al., 2003]. The DC-8 measurements in this paper also show the efficacy of volcanic emissions to destroy stratospheric ozone. We shall attempt to model this here.

\subsection{Modeling Experiments}

[10] A stratospheric chemical box model has been used along the volcanic cloud trajectory from eruption start to interception with the DC-8. A back trajectory cluster was calculated from the interception point to the eruption start time and location using 6 hourly operational analyses of winds and temperature from the European Centre for

Table 1. Measurements Discussed in This Paper

\begin{tabular}{lll}
\hline \multicolumn{1}{c}{ Measurements } & \multicolumn{1}{c}{ Instrument } & \multicolumn{1}{c}{ SOLVE PI (Reference) ${ }^{\mathrm{a}}$} \\
\hline $\mathrm{SO}_{2}, \mathrm{HCl}, \mathrm{HF}, \mathrm{HNO}_{3}, \mathrm{H}_{2} \mathrm{SO}_{4}, \mathrm{H}_{2} \mathrm{~S}, \mathrm{HCN}$ & CIMS & A Viggiano, J Ballenthin, D Hunton (4) \\
$\mathrm{NO}_{\mathrm{NO}} \mathrm{NO}_{\mathrm{y}}$ & Chemiluminescence & Y Kondo 20000227 \\
$\mathrm{CO}, \mathrm{CH}_{4}, \mathrm{~N}_{2} \mathrm{O}$ & DACOM IR Laser Spectrometer & Glen Sachse \\
$\mathrm{CO}_{2}$ & LICOR NDIR & Stephanie Vay \\
$\mathrm{In}$ situ ozone & FASTOZ NO chemilumimescence & M Avery \\
$\mathrm{H}_{2} \mathrm{O}$ vapor & Laser Hygrometer & R Herman R May (2) \\
$\mathrm{OH} / \mathrm{HO}_{2}$ & FAGE/LIF & William Brune (3) \\
0.42 to $20 \mu$ m particle data & FSSP-300 & Bruce Anderson (1) \\
Latitude, longitude, altitude & GPS DADS & C Sorenson, K Guenther \\
T, Pot T & DADS & C Sorenson, K Guenther \\
\hline
\end{tabular}

${ }^{a}$ References are 1, Hallar et al. [2004]; 2, May [1998]; 3, Brune et al. [1995]; and 4, Ballenthin et al. [2003]. All of these data are available on the Web at the SOLVE/THESEO 2000: http://cloud1.arc.nasa.gov/solve/ (P. A. Newman, SAGE III Ozone Loss and Validation Experiment, SOLVE, a NASA DC-8, ER-2 and High Altitude Balloon Mission, 1999). 
(a)

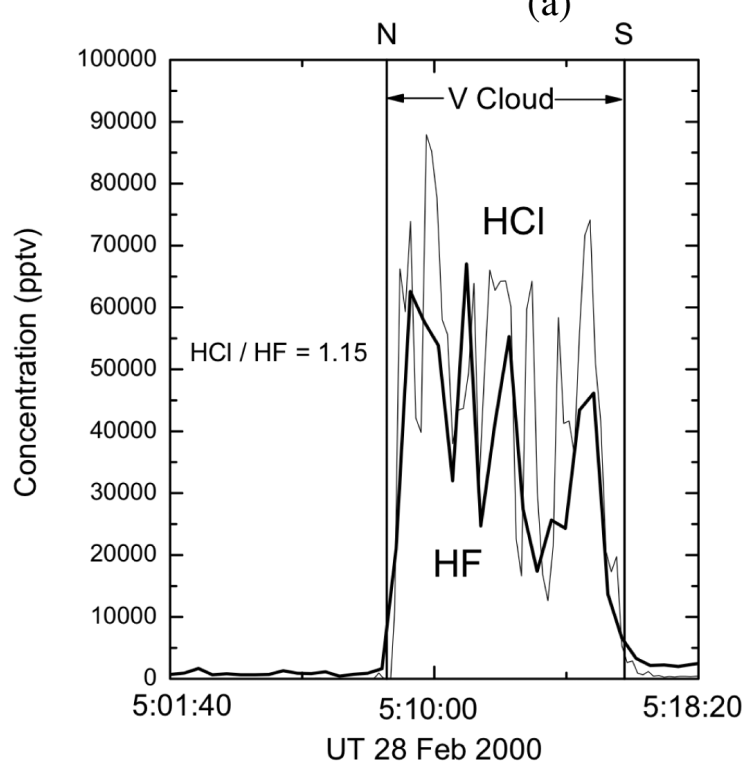

(b)

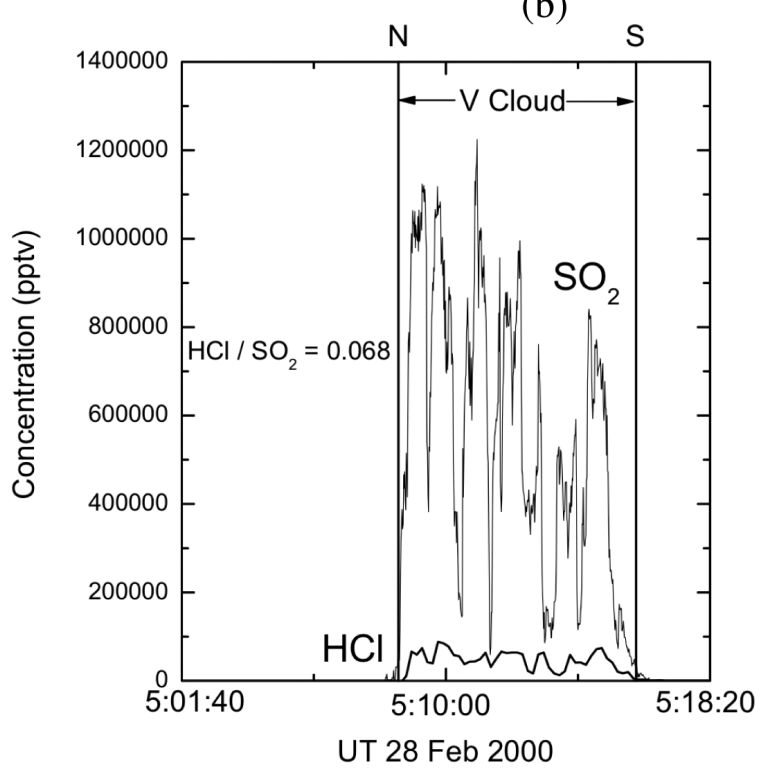

Figure 3. Data collected by the Chemical Ionization Mass Spectrometer (CIMS) instrument on the NASA DC-8 during the encounter of 28 February 2000. On the abscissa is UT on 28 February 2000. (a) Plot of mixing ratios (parts per trillion, volume) of $\mathrm{HCl}$ and $\mathrm{HF}$, with these gases showing sharp increases within the volcanic cloud. Note in Figure 1a that the time line represents an oblique transect through the plume $(\mathrm{N}$ side encountered first) generated by the latter stages of the explosive eruption 33-35 hours earlier. (b) Plot of mixing ratios (parts per trillion, volume) of $\mathrm{HCl}$ and $\mathrm{SO}_{2}$.

Medium-Range Weather Forecasts (ECMWF) [Methven, 1997; Cape et al., 2000]. The model contains detailed stratospheric chemistry and photochemical data are taken from Sander et al. [2003]. The total available PSC surface area of the individual particle types; liquid ternary solution $\mathrm{H}_{2} \mathrm{SO} 4 / \mathrm{H}_{2} \mathrm{O} / \mathrm{HNO}_{3}$ (STS), nitric acid trihydrate (NAT) and ice particles is determined by uptake of gas to solid phase and the number density assumed for each particle type [Hanson and Mauersberger, 1988; Carslaw et al., 1995]. Reactions on sulfuric acid tetrahydrate (SAT) particles were also included even though these particles have not been unambiguously detected in the stratosphere as conditions within the plume may be suitable for heterogeneous SAT nucleation. Chemical processing by a SAT dominated volcanic plume will be contrasted to the volcanically induced PSC processing in section 4.2 and 4.4. The box model does not include any microphysics or particle growth. In this study it is assumed that ice and NAT particles fall at velocities appropriate for particles of approximately 5 and $4 \mu \mathrm{m}$ diameters, respectively. STS and SAT aerosols are assumed to be $<1 \mu \mathrm{m}$ and so do not sediment out of the box model. Particle number densities were chosen to reflect the size distributions measured by the FSSP-300 probe (Figures 6a and $6 \mathrm{c}$ ) and FCAS II/NMASS, i.e., $2 \mathrm{~cm}^{-3}$ for ice, and $25 \mathrm{~cm}^{-3}$ for NAT, STS, and SAT aerosols. The box model does not contain oxidation of $\mathrm{SO}_{2}$ to $\mathrm{H}_{2} \mathrm{SO}_{4}$; however, this is likely to be of minor importance to this study as this oxidation has already been carefully estimated for the Hekla Cloud: $\sim 7 \%$ of $\mathrm{SO}_{2}$ was converted to $\mathrm{H}_{2} \mathrm{SO}_{4}$ within $35 \mathrm{hrs}$ of the eruption [see Rose et al., 2003, p. 126; Hunton et al., 2005].
[11] Initial background chemical fields were supplied by the three-dimensional off-line chemical transport model, SLIMCAT, also driven with 6 hourly ECMWF analyses. SLIMCAT has been used extensively in stratospheric chemistry investigations [Chipperfield et al., 1997; Chipperfield, 1999; Guirlet et al., 2000] and was used to investigate ozone loss during the same year as Hekla's eruption as part of the SOLVE/THESEO 2000 campaign [Sinnhuber et al., 2000; Ross et al., 2004; Robinson et al., 2005]. Potential vorticity diagnosed from the ECMWF analyses indicates that the volcanic cloud air parcel remains within the lower stratosphere throughout the trajectory.

\subsection{Volcanic Emissions Scenarios Used Within the Model}

[12] To consider what volcanic gases might be expected in the Hekla cloud, we first consulted data on volcanic gases directly sampled. Such data are generally sparse, and there are no magmatic gas samples available from Hekla. We selected three rare "uncontaminated" direct gas samples from volcanoes with similar rift tectonic associations (Table 2). One sample is from Surtsey, an effusive eruption in 19641967 not far from Hekla along the same rift, and two from Erta Ale, in Ethiopia, associated with the Afar hot spot. To represent HF we also have consulted sources such as Symonds et al. [1994], who looked at halogen emissions worldwide, and Oskarsson [1980, 1981], who studied F-rich tephra from Hekla apparently resulting from HF scavenging during eruption and ash fallout. Rose et al. [2003] used remote sensing to estimate a mass of $1 \mathrm{Tg}$ of $\mathrm{H}_{2} \mathrm{O}$ in the Hekla cloud and $\mathrm{SO}_{2}$ masses were similarly determined at $0.2 \mathrm{Tg}$, hence we infer that the Hekla volcanic 
(a)

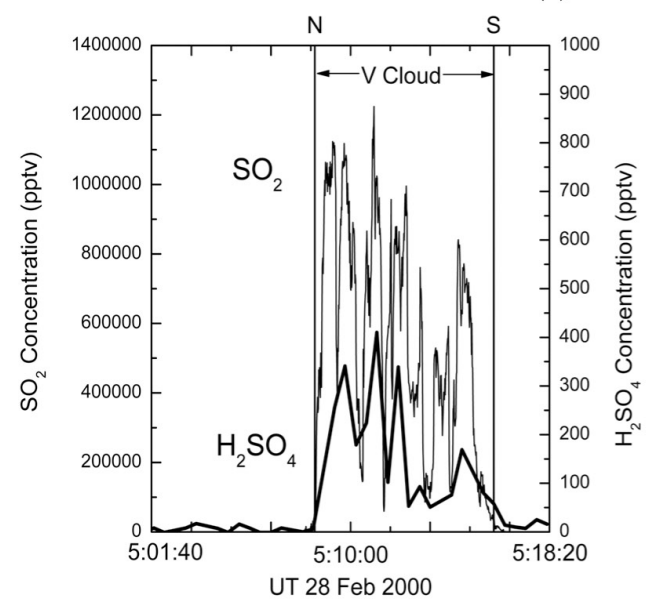

(c)

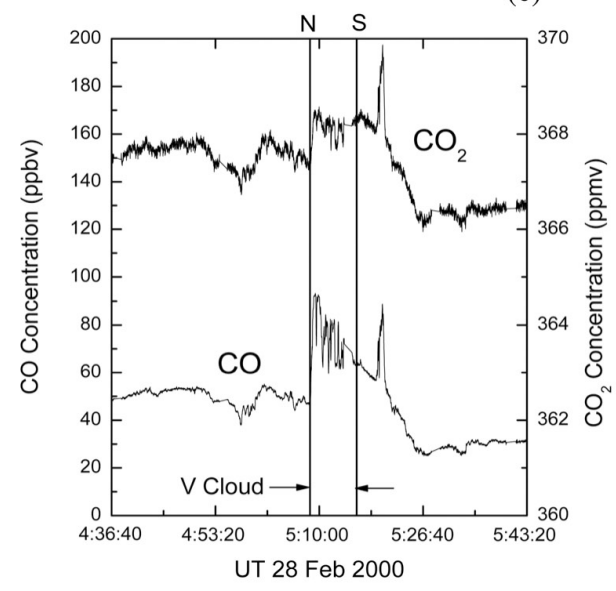

(e)

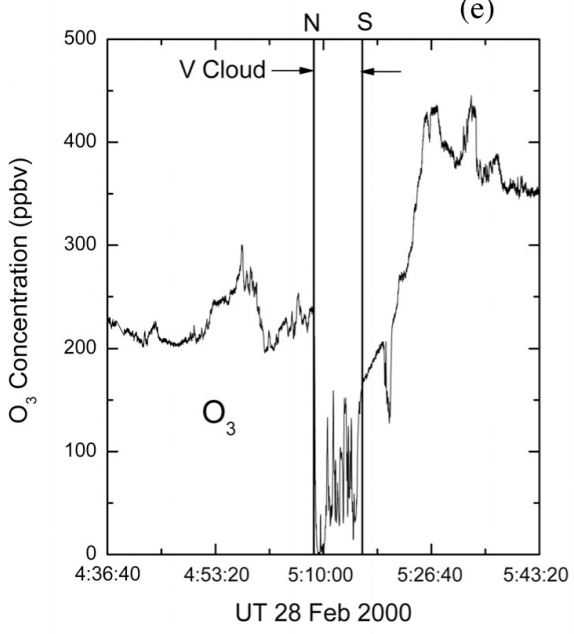

(b)

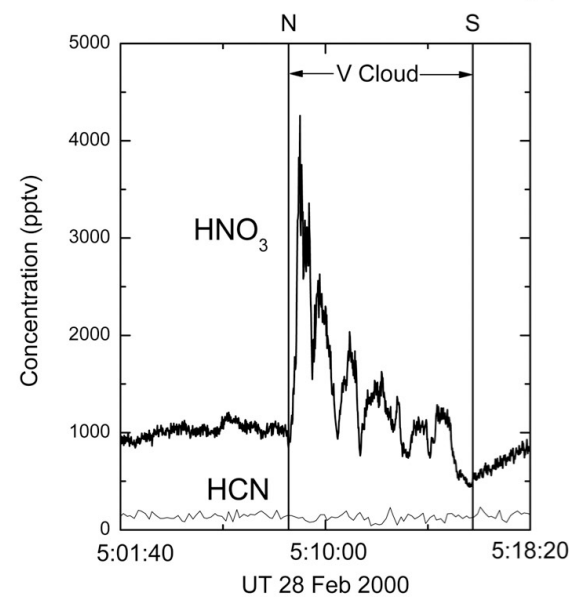

(d)
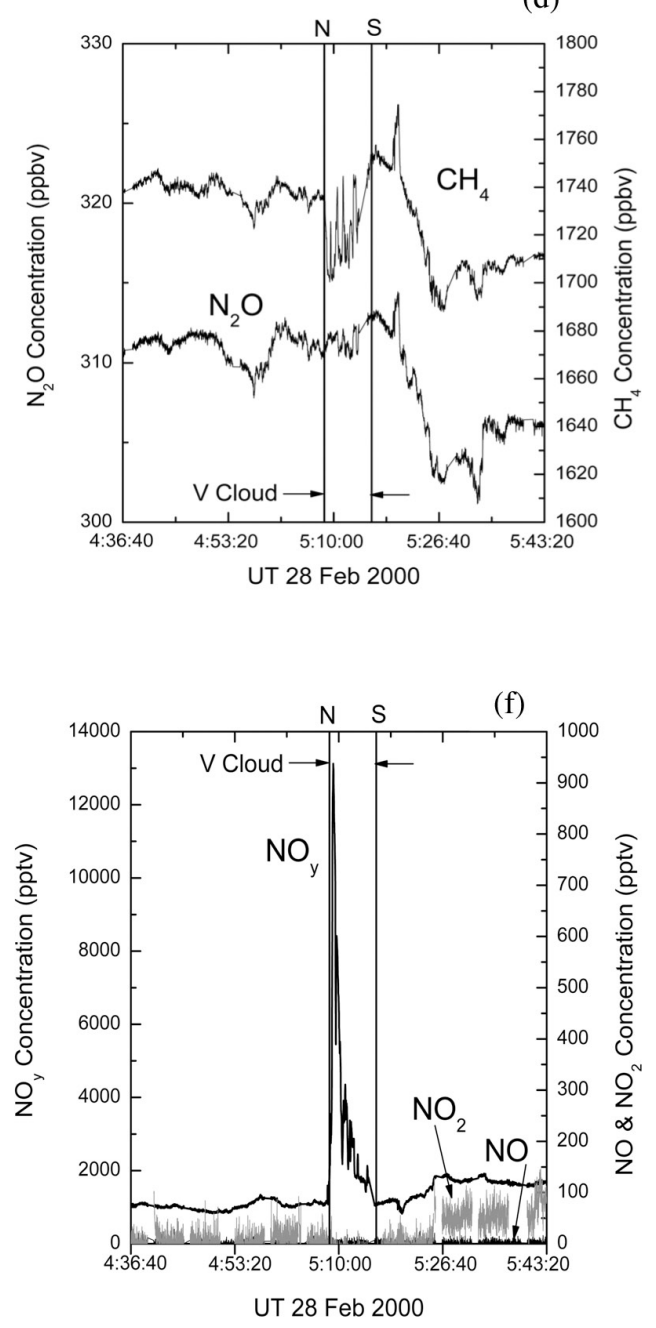

Figure 4. Measurements of Hekla volcanic cloud, 28 February 2000. (a) Chemical Ionization Mass Spectrometer results for gaseous $\mathrm{SO}_{2}$ and $\mathrm{H}_{2} \mathrm{SO}_{4}$ (b) CIMS results for gaseous $\mathrm{HNO}_{3}$ and $\mathrm{HCN}$. (c) Infrared laser spectrometry measurements of $\mathrm{CO}$, and LiCor IR measurements of $\mathrm{CO}_{2}$ (measurements described in Table 1). (d) Infrared laser spectrometry measurements of $\mathrm{CH}_{4}$ and $\mathrm{N}_{2} \mathrm{O}$. (e) In situ ozone mixing ratios (M. Avery, B. Anderson; NASA Langley RC). (f) Chemiluminescence data for $\mathrm{NO}, \mathrm{NO}_{2}$ and $\mathrm{NO}_{\mathrm{y}}$ (Kondo, University of Tokyo). 


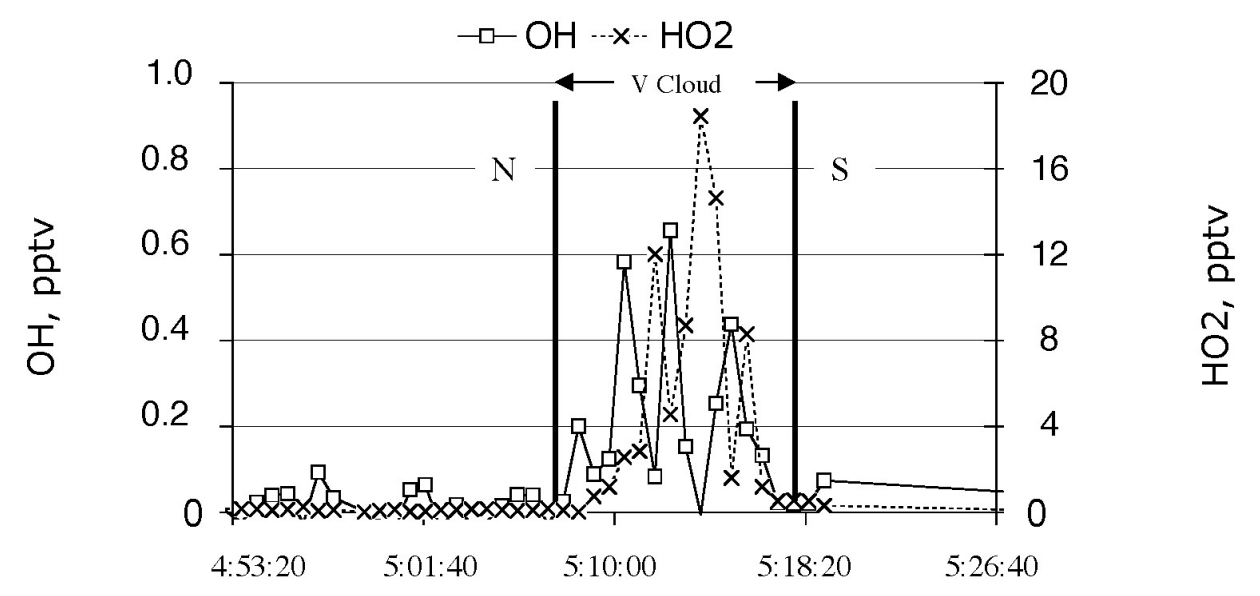

UT 28 Feb 2000

Figure 5. $\mathrm{OH}$ and $\mathrm{HO}_{2}$ mixing ratio measurements for the Hekla Volcanic cloud of 28 February 2000 (measurements described in Table 1).

cloud (if it is like mean high-temperature fumaroles compositions calculated from the data in Table 2) should have $\sim 0.3 \mathrm{Tg} \mathrm{CO}, \sim 0.03 \mathrm{Tg} \mathrm{H}, \sim 0.02 \mathrm{Tg} \mathrm{CO}, \sim 0.02 \mathrm{Tg} \mathrm{H}_{2} \mathrm{~S}$, $\sim 0.02 \mathrm{Tg} \mathrm{HCl}$, and $\sim 0.02 \mathrm{Tg} \mathrm{HF}$. Scaling these proportions to the $1-1.2$ ppmv measured $\mathrm{SO}_{2}$ mixing ratio (Figure $3 \mathrm{~b}$ ), we would (assuming no reactions and removal in the volcanic plume during 35 hours) expect, as a first-order estimate, the other gases in the volcanic cloud would have the following compositions: $1.4-1.6 \mathrm{ppmv} \mathrm{CO}_{2}, 0.2 \mathrm{ppmv}$ $\mathrm{H}_{2}, 52-63$ ppbv CO, 82-98 ppbv $\mathrm{H}_{2} \mathrm{~S}, 50-60$ ppbv $\mathrm{HCl}$, and 50-60 ppbv HF.

[13] Table 2, combined with estimates of the nitrogen species concentrations made using the aircraft measurements (section 2), was used to compile a series of emissions scenarios to initialize the model. These concentrations were added to background concentrations within the box model (see Table 3 for details) approximately above Hekla at a time corresponding to the start of the eruption. Hekla $\mathrm{HCl}$ concentrations are estimated to reach $68 \mathrm{ppb}$, although measurements on the DC-8 suggest a maximum of $60 \pm$ $30 \mathrm{ppb}$. A smaller value of $45 \mathrm{ppb}$ has been chosen to initialize the box model so that $\mathrm{HCl}$ levels match DC-8 values after conversion of $\mathrm{ClONO}_{2}$ to hydrogen chloride during the run. Uptake of $\mathrm{HCl}$ onto particles was not found to alter gaseous concentrations permanently.

[14] Satellite brightness temperatures diagnose volcanic cloud temperatures of 203-218 K near the start of the eruption [Rose et al., 2003]. Temperatures used by the model (calculated from ECMWF analyses) suggest the volcanic cloud was $206 \mathrm{~K}$ at the start, falling to $200 \mathrm{~K}$ at interception with the DC-8. This is up to $3 \mathrm{~K}$ warmer than satellite brightness temperatures at the start but returning to realistic temperatures at interception. Therefore a reduction of initial temperatures within the model by $2 \mathrm{~K}$ may be realistic. Volcanic cloud chemistry is very sensitive to temperature as inclusion of the volcanic emissions of nitric acid and water vapor brings the threshold of ice formation to within $2 \mathrm{~K}$ of the model temperatures. The sensitivity of the volcanic cloud chemistry to temperature was investigated by imposing a cooling of $2-8 \mathrm{~K}$ at the trajectory start which relaxed back to ambient analyses temperatures over a time period of 2 days. This is intended to simulate a possible temperature anomaly brought about by an initial adiabatic cooling due to the explosive eruption, which is a subgrid-scale event for the ECMWF analyses and is not captured, followed by decay of

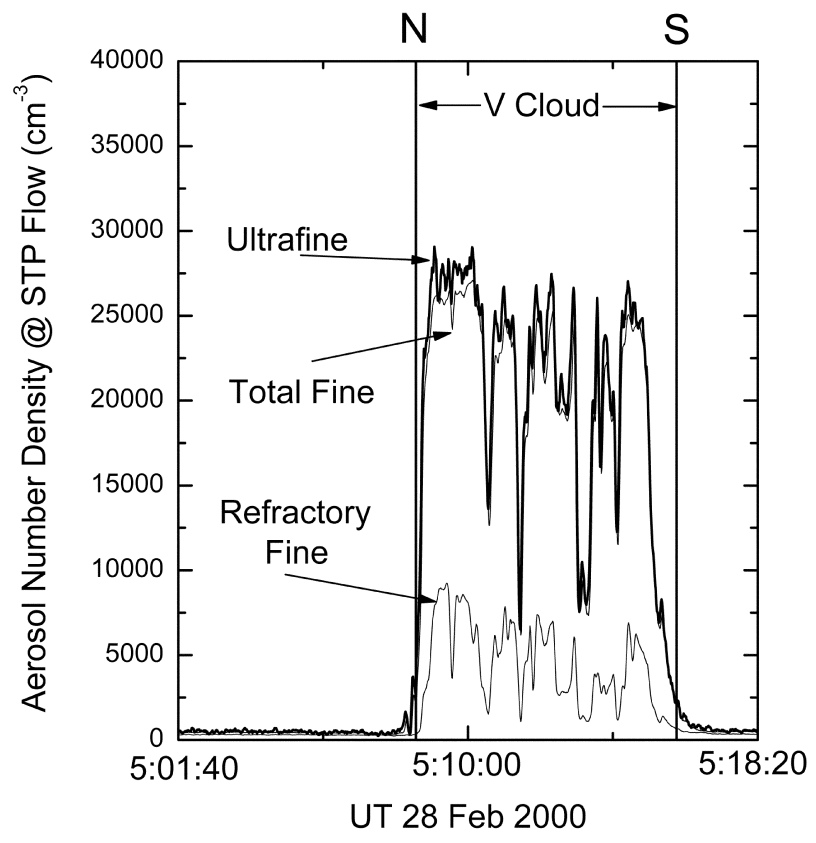

Figure 6a. Particle number densities $\left(\mathrm{N} \mathrm{m}^{-3}\right)$ in diameter range of 4 to $2200 \mathrm{~nm}$ for Hekla Volcanic Cloud of 28 February 2000 (B. Anderson, Langley Research Center). Black line outlines number density of ultrafine particles; upper gray line is total fine (volatile and nonvolatile) particles and lower gray line is refractory fine particles. 

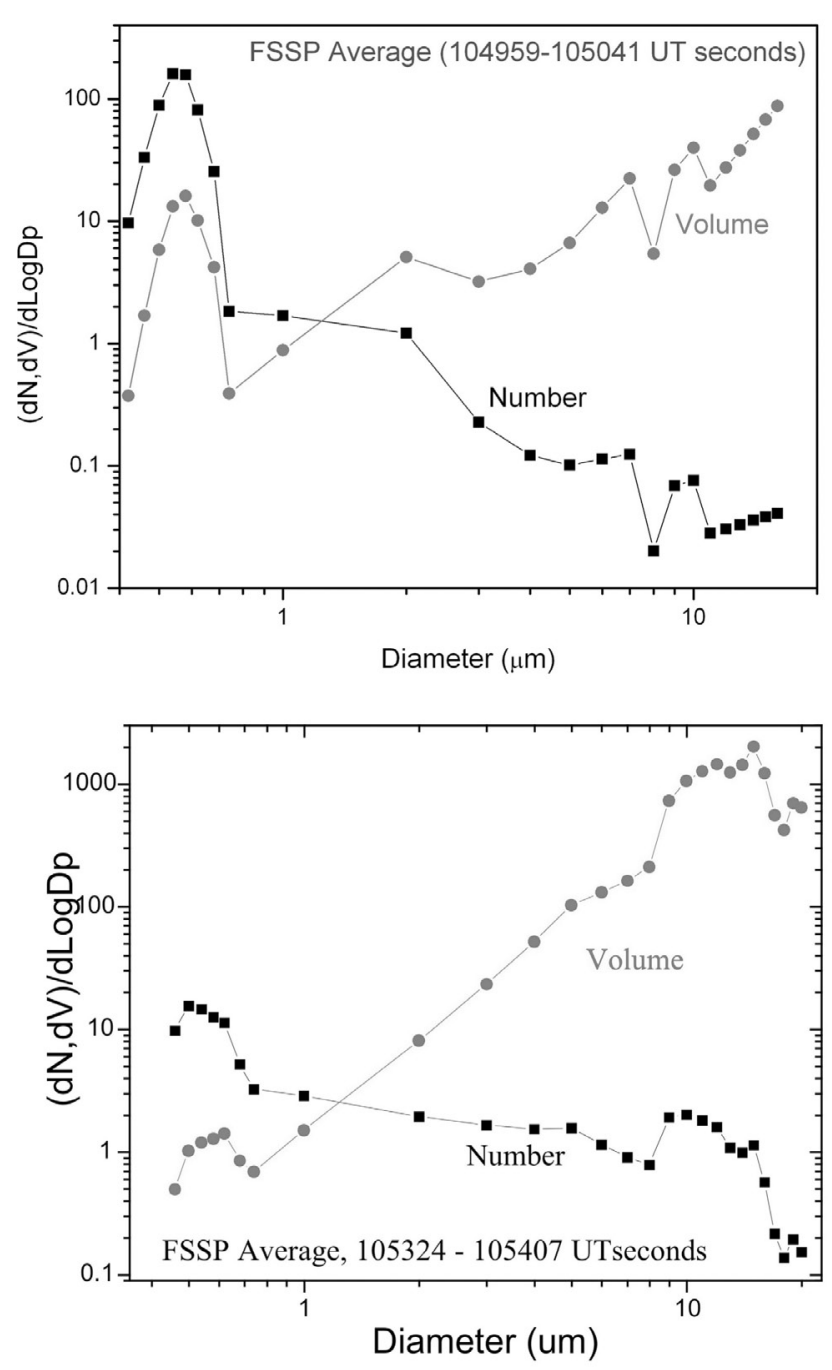

Figure 6b. Particle size distributions (by number (squares) and volume (circles)) in range of 0.42 to $20 \mu \mathrm{m}$ for Hekla Volcanic cloud of 28 February 2000. (top) Data for the north side of the volcanic cloud, (bottom) from the south side. Note different particle number scales. The data are based on the FSSP-300 measurements and the procedure is explained by Hallar et al. [2004].

the anomaly to ambient temperatures on a timescale appropriate for zonal mixing and radiative transfer.

\section{Results and Discussion}

\subsection{Comparison of Expected With Measured Gas Composition and Amount}

[15] Here we compare the first-order estimates based on Table 2 (0.9-1.6 ppmv $\mathrm{CO}_{2}, 5-21$ ppbv $\mathrm{H}_{2}, 23-73 \mathrm{ppbv}$ $\mathrm{CO}, 43-115$ ppbv $\mathrm{H}_{2} \mathrm{~S}, 29$ ppbv $\mathrm{HCl}$, and $14-32$ ppbv HF) to the anomalies observed in Figures 3 and 4 ( $\sim 1$ ppmv $\mathrm{CO}_{2}, \sim 20 \mathrm{ppbv} \mathrm{CO}, \sim 0 \mathrm{ppbv} \mathrm{H}_{2} \mathrm{~S}, \sim 68 \mathrm{ppbv} \mathrm{HCl}$, and $\sim 60$ ppbv $\mathrm{HF}$ ). The agreement of $\mathrm{CO}_{2}$ is good, but the anomaly suffers from a poor peak to background relationship. The agreement for $\mathrm{HCl}$ and $\mathrm{HF}$ we consider good, probably within the uncertainty of the gas composition assumed. Since substantial dissolution of $\mathrm{HCl}$ and $\mathrm{HF}$ by liquid water which forms in the ascending eruption column is expected in "wet plume" conditions (e.g., Textor et al. [2004], who built this process into the ATHAM model), we note that the relatively "dry plume" environment (high latitude atmospheric profiles are much drier than tropical ones) of the Hekla event did not appear to do much scavenging of $\mathrm{HCl}$ and $\mathrm{HF}$ and a majority of these gases reached the stratosphere. Perhaps in tropical eruptions, where tropospheric $\mathrm{H}_{2} \mathrm{O}$ is much higher, scavenging is more important. Leaving aside the $\mathrm{H}_{2}$ comparison for lack of data, the remaining gases appear to be absent or underrepresented in the real data. $\mathrm{H}_{2} \mathrm{~S}$ had no measured anomaly in CIMS data and CO approaches the low end of its expected range. The conversion of $\mathrm{H}_{2} \mathrm{~S}$ in the atmosphere (not well constrained in volcanic cloud conditions) may be of the order of one to 5 days [Graedel, 1977; Aiuppa et al., $2005 \mathrm{~b}$ ], with faster conversion rates where $\mathrm{OH}$ is present. We suggest that these two gases were oxidized in the Hekla volcanic cloud, a conclusion shared by Hunton et al. [2005].

[16] The source of these volcanic gases is here assumed to be magma, but a comparison of the gas masses in the explosive event $(\sim 2 \mathrm{Tg})$ to the mass of tephra fall (DRE volume $=0.002 \mathrm{~km}^{3}$ equivalent to $\sim 5.4 \mathrm{Tg}$ of magma) requires a gas release in this eruption equivalent to $40-50 \%$ gas (although this neglects fine ash transported and deposited beyond the limits of the region sampled on the ground in Iceland). Most volcanologists would be surprised by this proportion of gas release but it is less surprising if we consider the total magnitude of the eruption (including effusive lava) where that gas/magma ratio is about $0.7 \%$. Perhaps before eruption the gas resides near the top of the magma reservoir and is erupted first, as suggested by Wallace et al. [2003]. Considering the rather low mass proportion of ash in this explosive event, it is likely that the Hekla volcanic cloud would never have reached the lower stratosphere unless the gas proportion was very high, and the heat of hot volcanic gas was more important in the buoyancy of the cloud than heat exchange with the ash particles (the usually dominant source of heat; see Sparks et al. [1997, chapter 7]). Sharma et al. [2004] measured the S concentration in melt inclusions within the Hekla 2000 tephra and lavas ( $900 \mathrm{ppm})$ and compared them to groundmass glass $(310 \mathrm{ppm})$. They then estimated $\mathrm{SO}_{2}$ release to the atmosphere for the entire eruption based on the difference in glass $\mathrm{S}$ content and corrected for crystallinity $(0.48 \mathrm{Tg})$. This mass calculation is only relevant if one assumes that the gas from all the erupted 2000 magma escaped entirely during the explosive phase. Hunton et al. [2005] have shown that even the later gas encountered by the SOLVE/THESEO 2000 mission were probably released in the initial phase and we believe the stratospheric arrival of gas released gradually from a small fissure event is not even possible. An equivalent calculation for "petrologic method" $\mathrm{SO}_{2}$ if one scales the volume by the tephra mass/ total mass $(5.4 \mathrm{Tg} / 414 \mathrm{Tg}$ ) is about $0.006 \mathrm{Tg}$ (about $1 / 30$ of what was observed). Thus several lines of evidence suggest an early gas-rich eruption which may have derived gas from magma that either erupted later or did not erupt. This statement differs in emphasis from the conclusions of Sharma et al. [2004], who compared the gas volume of the explosive phase with the total volume of the eruption 


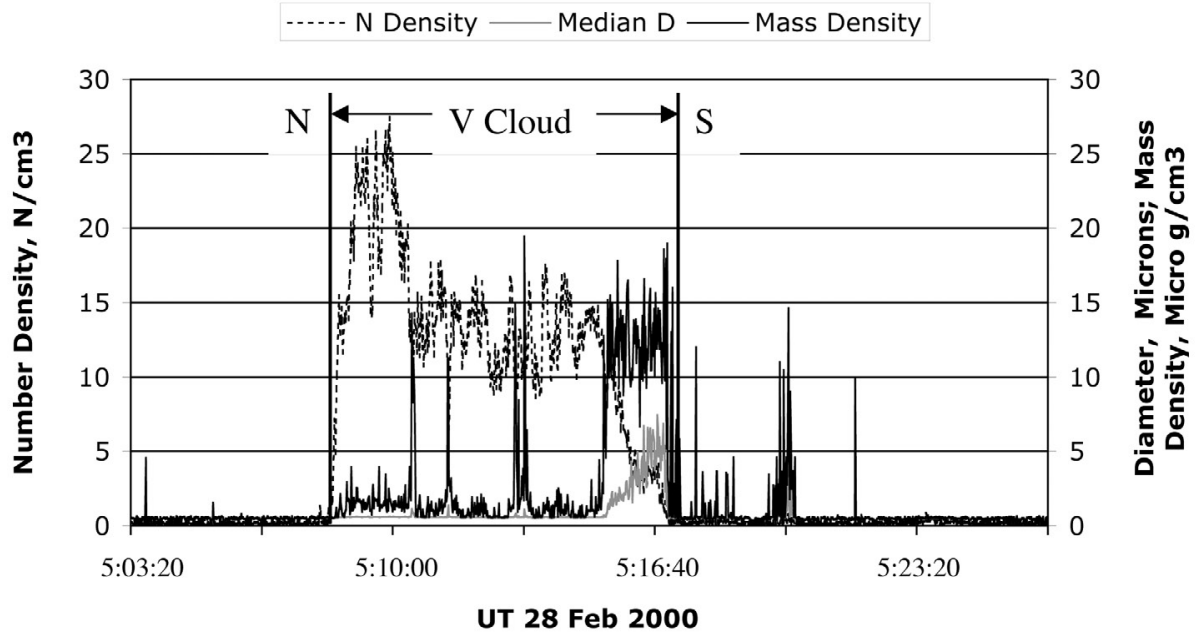

Figure 6c. FSSP-300 (Table 1) data for particles $0.42-20 \mu \mathrm{m}$ in the Hekla Volcanic cloud of 28 February 2000. Black line plots the median particle diameter in microns, dashed line the particle number density in $\left(\mathrm{m}^{-3}\right)$, and gray plots the total mass density in $\mu \mathrm{g} \mathrm{m}^{-3}$.

(including the 11 day fissure event), and emphasized near parity.

\subsection{Volcanic Particles}

\subsubsection{Particle Size Distributions and Compositions}

[17] Four types of common stratospheric particles are considered within the model: ice, NAT, STS, and SAT particles. From the aircraft particle measurements, the particle size distribution on the south side of the volcanic cloud (Figure 6b) showed two modes, one peaking at about $0.5 \mu \mathrm{m}$ and the other between 10 and $20 \mu \mathrm{m}$. On the north side, the $0.5 \mu \mathrm{m}$ peak is dominant. The model predicts that ice, NAT, STS, and SAT particles are likely to be present within the volcanic cloud although ice particles may be restricted to the colder (about $2 \mathrm{~K}$ lower) south side (based on the calculated threshold temperature for ice existence at these values for pressure and water vapor mixing ratio). This, plus the faster expected growth rates of NAT and ice particles at lower temperatures might explain the dominance of larger particles detected in the southern volcanic cloud [Carslaw et al., 1995; Carslaw and Clegg, 1997; Koop et al., 1997]. Satellite infrared brightness temperature difference measurements [Rose et al., 2003] indicate that ice was the optically dominant component of the Hekla volcanic cloud in the first hours. Remote sensing also strongly suggests that the Hekla cloud was fading by interception with the DC-8 (the mass of ice had decreased by at least a factor of 5 from its peak) and had a mass of ice that was

\section{JPL Laser Hygrometer}

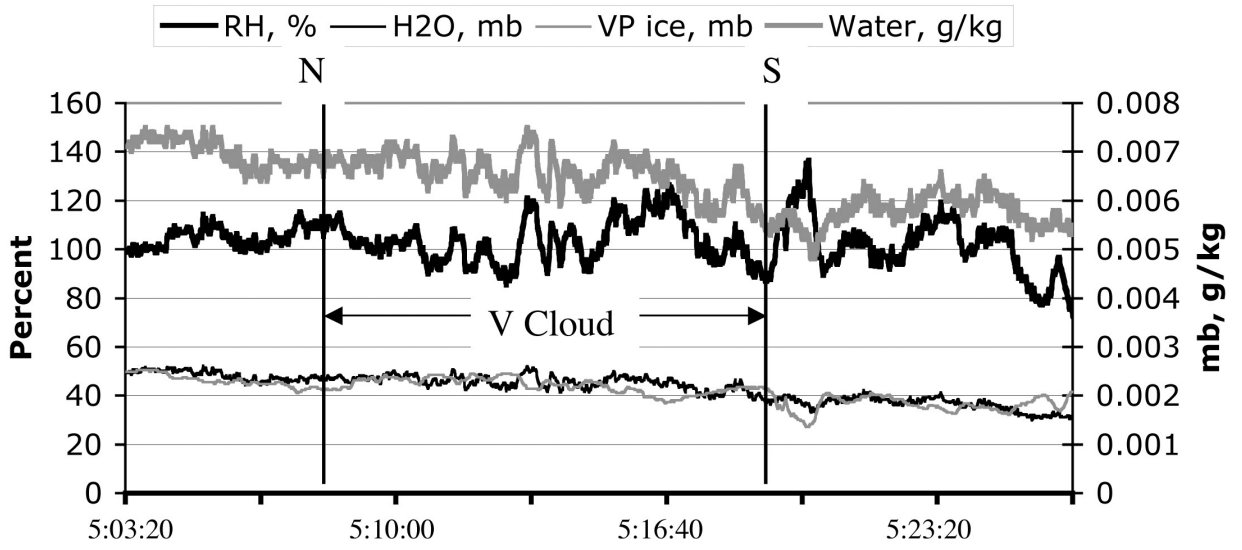

UT 28 Feb 2000

Figure 6d. Parameters relating to cloud water for the Hekla volcanic cloud of 28 February 2000. Top black is relative humidity in \%, top gray is total cloud water (mainly ice) in $\mathrm{g} \mathrm{kg}^{-1}$, bottom black is $\mathrm{H}_{2} \mathrm{O}$ vapor pressure in mbar, and bottom gray is $\mathrm{H}_{2} \mathrm{O}$ vapor pressure over ice in mbar. 
FSSP-300

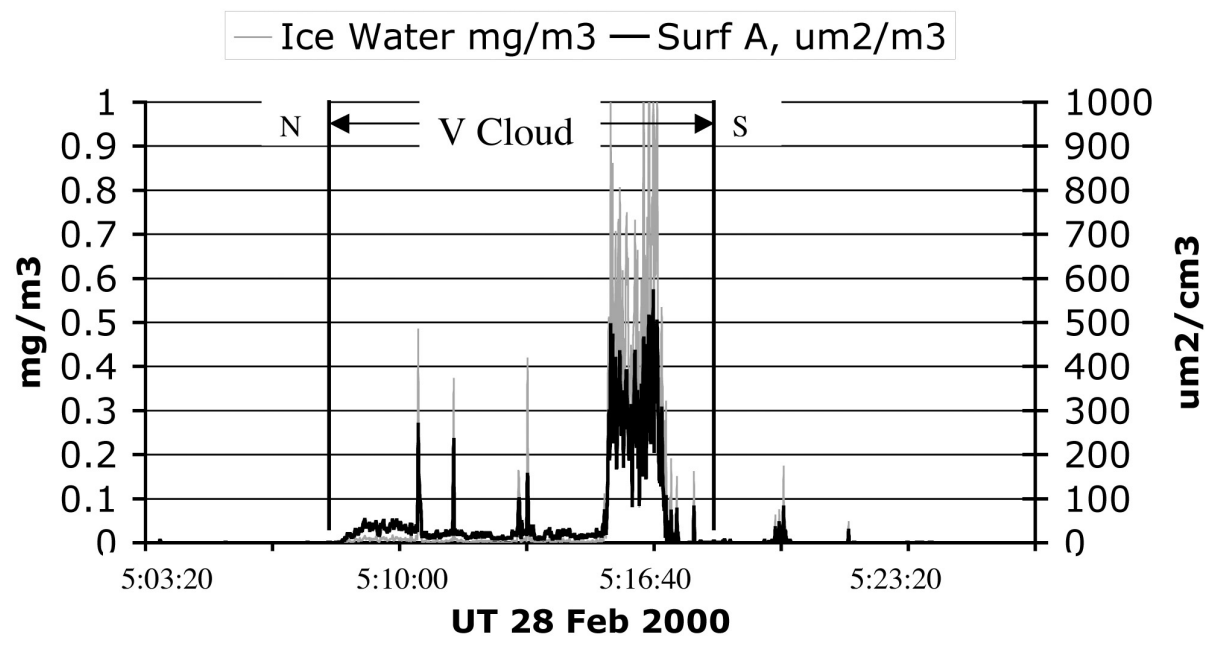

Figure 6e. Particle data for Hekla Volcanic cloud of 28 February 2000 from FSSP-300 (Table 1). Gray line plots ice water mass in $\mathrm{mg} \mathrm{m}^{-3}$. Black line plots total particle surface area in $\mu \mathrm{m}^{2} \mathrm{~cm}^{-1}$.

$<0.2 \mathrm{Tg}$ at the time of the encounter. This is consistent with the temperature profile along the volcanic cloud trajectory used in the box model with was taken from ECMWF analyses (Figure 7a) which shows a temperature minimum about 20 hours after the eruption.

[18] Volcanic ash is not known to show prominent proportions of submicron particles and even particles in the 1$20 \mu \mathrm{m}$ size range are far less important in the overall mass of ash erupted than larger ones [e.g., Horwell et al., 2003]. However, in Figure 6a, where the total number of particles is plotted spatially for the cloud traverse, we see that the proportion of nonvolatile "heated" particles is nearly constant at about $25-30 \%$. This is true, in spite of the marked differences in particle sizes across the cloud shown in Figure 6c. This seems to suggest that fine volcanic ash particles ranging from 0.5 to $20 \mu \mathrm{m}$ are found all across the volcanic cloud.

\subsubsection{Volcanically Induced Polar Stratospheric Clouds (PSC)}

[19] Background nitric acid and water vapor concentrations are too low for PSC formation at $1.72 \mathrm{ppb}$ and 3.67 ppm, respectively. Nonetheless the model predicts that NAT PSCs are formed along the trajectory within a few hours of eruption, with inclusion of Hekla concentrations, at ambient temperatures. Generation of ice PSCs requires a cooling of $2 \mathrm{~K}$ at the trajectory start with subsequent relaxation to ambient temperatures in order to enable them to form at the temperature minimum on the 27 February. Additional cooling increases the duration of ice PSCs, and they are present throughout the trajectory with an initial cooling of $8 \mathrm{~K}$ and subsequent relaxation. The relationship between the predicted particle surface area density and initial trajectory temperature is shown in Figure $7 \mathrm{~b}$. The highest values of surface area density diagnosed by FCAS II are only captured by the model when a substantial cooling of $6-8 \mathrm{~K}$ is imposed on the start. This discrepancy might be accounted for by absorption of nitric acid and water vapor onto ash condensation nuclei within the volcanic cloud and hence the generation of large particles more quickly than diagnosed by the simple treatment within the model.

[20] The occurrence of PSC and the availability of particle surface area for heterogeneous reactions have important implications for the reaction rates and mechanisms occurring in the volcanic cloud (e.g., Table 4). These implications are discussed in more detail later (section 4.4) but it is worth noting that the choice of initial Hekla concentrations, as well as the temperature profile as described above, has significant effects on the surfaces available within the model. For example, $\mathrm{H}_{2} \mathrm{SO}_{4}$ is not a reactive species within the model; however, it is used to calculate the amount of $\mathrm{H}_{2} \mathrm{SO}_{4}$ particle surface area. Background $\mathrm{H}_{2} \mathrm{SO}_{4}$ is low, $0.073 \mathrm{ppb}$, as it is a long time since the last major eruption, Mount Pinatubo, in 1991 [Bekki and Pyle, 1994]. The Hekla volcanic cloud therefore represents a significant perturbation to local stratospheric levels of $\mathrm{H}_{2} \mathrm{SO}_{4}$. In scenario $\mathrm{F}$ (Table 3), both the measured gas phase (Figure 4) and solid phase $\mathrm{H}_{2} \mathrm{SO}_{4}$ (derived as $7 \%$ of $\mathrm{SO}_{2}$ in Rose et al. [2003]) are supplied to the box model (70.4 ppb). In all other scenarios only the measured gas phase $\mathrm{H}_{2} \mathrm{SO}_{4}$ is used. For scenario $\mathrm{F}$, the heterogeneous

Table 2. Selected Direct Samples of Volcanic Gases From Rift Volcanoes $^{\mathrm{a}}$

\begin{tabular}{llll}
\hline \multicolumn{1}{c}{ Volcano } & Erta Ale & Erta Ale & Surtsey \\
\hline $\mathrm{T},{ }^{\circ} \mathrm{C}$ & 1130 & 1032 & 1125 \\
$\mathrm{H}_{2} \mathrm{O}$, mol \% & 77.2 & 69.4 & 81.1 \\
$\mathrm{CO}_{2}$ & 11.3 & 17.2 & 9.29 \\
$\mathrm{SO}_{2}$ & 8.34 & 9.46 & 4.12 \\
$\mathrm{H}_{2}$ & 1.39 & 1.57 & 2.80 \\
$\mathrm{CO}$ & 0.44 & 0.75 & 0.69 \\
$\mathrm{H}_{2} \mathrm{~S}$ & 0.68 & 1.02 & 0.89 \\
$\mathrm{HCl}$ & 0.42 & nd & nd \\
$\mathrm{HF}$ & nd & nd & nd \\
$\mathrm{S}_{2}$ & nd & 0.59 & 0.25 \\
$\mathrm{COS}$ & nd & 0.02 & nd \\
\hline
\end{tabular}

${ }^{\mathrm{a}}$ From Symonds et al. [1994]; nd, no data. 
Table 3. Gaseous Emissions of Hekla Supplied to the Chemical Box Model

\begin{tabular}{|c|c|c|c|c|c|c|}
\hline \multirow[b]{2}{*}{ Species } & \multicolumn{6}{|c|}{ Emissions Scenario, ppb } \\
\hline & A & $\mathrm{B}$ & $\mathrm{C}$ & $\mathrm{D}$ & $\mathrm{E}$ & $\mathrm{F}$ \\
\hline $\mathrm{HCl}$ & 45 & 45 & 45 & 80 & 80 & 45 \\
\hline $\mathrm{HBr}$ & 0.8 & 0.8 & 0.8 & 0.8 & 0.8 & 0.8 \\
\hline $\mathrm{HF}$ & 60 & 60 & 60 & 60 & 60 & 60 \\
\hline $\mathrm{H}_{2} \mathrm{SO}_{4(\mathrm{~g})}$ & 0.4 & 0.4 & 0.4 & 0.4 & 0.4 & 70.4 \\
\hline $\mathrm{H}_{2} \mathrm{O}_{\text {(tot) }}$ & 6000 & 6000 & 6000 & 6000 & 6000 & 6000 \\
\hline $\mathrm{CO}$ & 20 & 20 & 20 & 20 & 20 & 20 \\
\hline $\mathrm{NO}_{\mathrm{y}}$ & & & & & & \\
\hline $\mathrm{HNO}_{3}$ & 4 & 4 & 4.0 & 4 & 4 & 4 \\
\hline $\mathrm{ClONO}_{2}$ & 0 & 8 & 0 & 0 & 8 & 0 \\
\hline $\mathrm{N}_{2} \mathrm{O}_{5}$ & 4 & 0 & 0 & 4 & 0 & 4 \\
\hline $\mathrm{NO}_{\mathrm{x}}$ & 0 & 0 & 8 & 0 & 0 & 0 \\
\hline
\end{tabular}

surface area is dominated by SAT particles at ambient temperatures (Figure 7d) compared to NAT dominance in scenario A (Figure 7c). This affects the rate of some key reaction ozone destruction reactions, for example the heterogeneous destruction of $\mathrm{N}_{2} \mathrm{O}_{5}$ is enhanced (compared to ice or NAT, Figure 8) thus reducing the rate of $\mathrm{ClO}_{\mathrm{x}}$ generation, although this does not impact ozone loss rates (see section 4.4). However, even for emission scenario F, a $2 \mathrm{~K}$ cooling is sufficient for ice particles to form within the model increasing chlorine activation rates.

\subsection{Nitrogen Chemistry}

\subsubsection{Origin of Volcanic Nitrogen Species}

[21] Both $\mathrm{HNO}_{3}$ and $\mathrm{NO}_{\mathrm{y}}$ are significantly elevated in Hekla's volcanic cloud at the time of the aircraft interception (Figures $4 \mathrm{~b}$ and $4 \mathrm{f}$ ). Elevated levels of $\mathrm{NO}, \mathrm{NO}_{2}$ and $\mathrm{HNO}_{3}$ have all previously been measured in volcanic clouds from eruptive events and above lava flows and lava lakes [Hobbs et al., 1991; Bandy et al., 1982; Hobbs et al., 1982; Huebert et al., 1999; Mather et al., 2004a, 2004b]. Mather et al. [2004a] proposed two possible mechanisms for the formation of $\mathrm{NO}_{\mathrm{x}}$ and $\mathrm{HNO}_{3}$ in volcanic clouds: thermal fixation of atmospheric $\mathrm{N}_{2}$, forming $\mathrm{NO}$ due to the heat from the magma or magmatic gases themselves or in the case of ashy volcanic clouds thermal fixation due to the heat from volcanic lightning. Mather et al. [2004a] demonstrated that $\mathrm{HNO}_{3}$ is a detectable constituent of several active volcanic clouds and is present in molar ratios of $\mathrm{HNO}_{3} /$ $\mathrm{SO}_{2}$ of 0.01 to 0.07 . As the volcanic clouds where the measurements were made were predominantly ash free, this $\mathrm{HNO}_{3}$ was assumed to originate from thermal fixation of $\mathrm{N}_{2}$ above hot magma bodies. In the Hekla volcanic cloud $\mathrm{HNO}_{3}$ has a peak mixing ratio of $\sim 4$ ppbv, a concentration which implies molar $\mathrm{HNO}_{3} / \mathrm{SO}_{2}$ of $\sim 0.004$ (given the peak $\mathrm{SO}_{2}$ mixing ratio of $\sim 1 \mathrm{ppmv}$ ), which is reasonably consistent with these previous measurements of fixed nitrogen resulting from volcanic heat. However, observations (a)

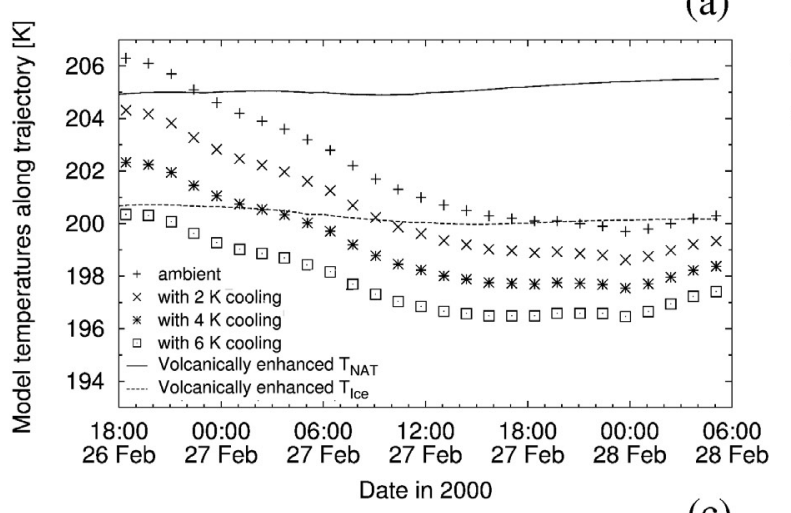

(c)

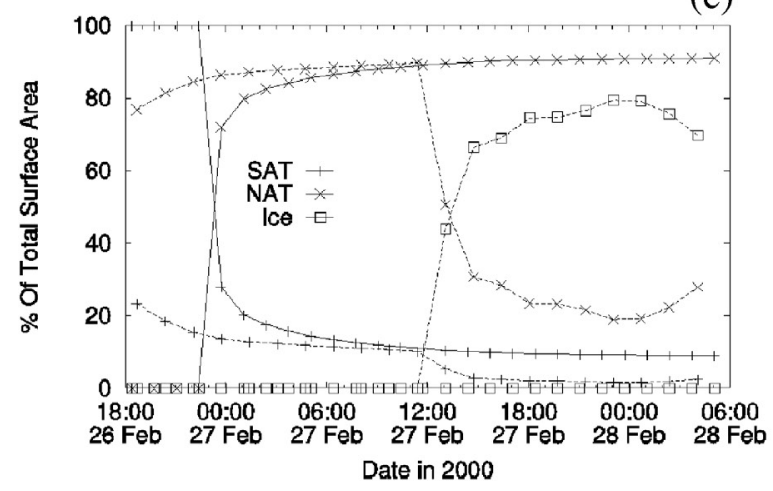

(b)
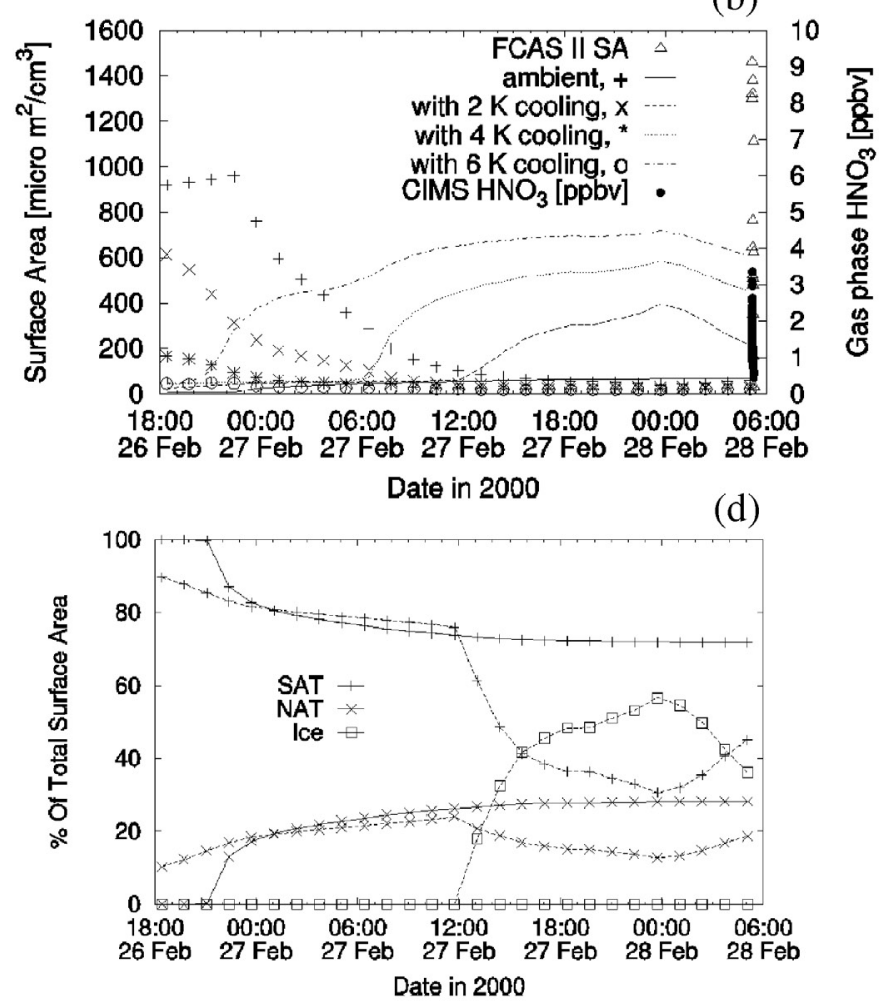

Figure 7. (a) Box model temperatures along the plume trajectory (symbols), with imposed initial cooling, NAT and ice PSC threshold formation temperatures are also shown (solid and dashed line, respectively). (b) Box model predictions of available heterogeneous surface area and gas phase nitric acid scenario A, compared to FCAS II and CIMS measurements. (c) Partitioning of particle surface area by particle type within the box model at ambient ECMWF temperatures (solid lines) and with a $2 \mathrm{~K}$ cooling (dashed lines) for integration A. (d) As for Figure 7c but for integration F. 
Table 4. Main Reactions Contributing to $\mathrm{O}_{3} \operatorname{Loss}^{\mathrm{a}}$

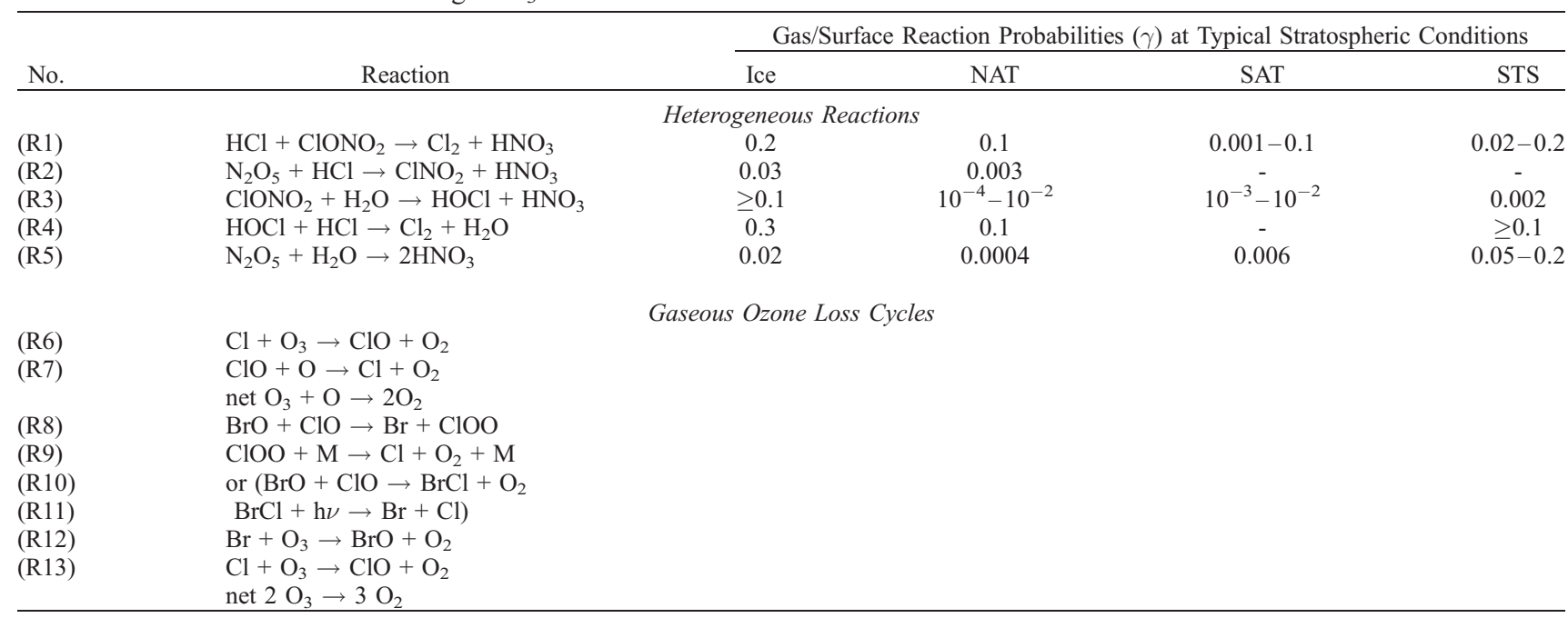

\footnotetext{
${ }^{a}$ Kinetic data are taken from Sander et al. [2003]. Relative importance of heterogeneous reactions on the various plume aerosols is indicated.
} Heterogeneous reactivity of ash is neglected.

suggest that Hekla's eruption volcanic cloud was marked with lightning [Arason, 2005]. Using a tephra mass of $\sim 5.4 \mathrm{Tg}$ for the explosive phase of the eruption (see section 4.1 and Haraldsson et al. [2002]), and the calculation method detailed by Navarro-González et al. [1998] and Mather et al. [2004a], we can estimate that the NO production in the Hekla volcanic cloud due to volcanic lightning to be $\sim 5 \times 10^{6}$ moles. Combining this with an estimate of the initial $\mathrm{SO}_{2}$ mass in the cloud of order $0.2 \mathrm{Tg}$ [Rose et al., 2003], yields a molar ratio of $\mathrm{NO} / \mathrm{SO}_{2}$ of order 0.001 , which is consistent with that observed. Therefore it is difficult to distinguish which mechanism the observed nitrogen species originated from. Another possible source of the oxidized nitrogen species is the oxidation during transport of gaseous $\mathrm{NH}_{3}$ released in the eruption cloud. Oskarsson $[1980,1981]$ suggests that $\mathrm{NH}_{3}$ is present in Hekla's volcanic gas based on the occurrence of salammoniac in incrustations. We do not know whether the $\mathrm{NH}_{3}$ levels are high enough to account for the levels of reactive nitrogen species observed. Thermodynamic calculations to check $\mathrm{NH}_{3}$ stability [e.g., Symonds et al., 1994] suggest that rare reports of $\mathrm{NH}_{3}$ in hightemperature volcanic gases reflect heating and pyrolysis of organic material and not original magmatic conditions. There is also uncertainty as to whether $\mathrm{NH}_{3}$ would be efficiently converted to $\mathrm{NO}_{\mathrm{x}}$ on these timescales and under volcanic cloud conditions [Lee et al., 1997].

[22] To produce $\mathrm{HNO}_{3} \mathrm{NO}$ generated by either mechanism or by emitted $\mathrm{NH}_{3}$ must be oxidized. The presence of elevated $\mathrm{OH}$ and $\mathrm{HO}_{2}$ in Hekla's volcanic cloud (see Figure 5 and section 4.5) might facilitate the oxidation of $\mathrm{NO}$ to $\mathrm{HNO}_{3}$ [Logan, 1983; Mather et al., 2004a].

\subsection{2. $\mathrm{NO}_{\mathrm{y}}$ and Nitrogen Speciation in the Volcanic Cloud}

[23] The measurements by Koike et al. [2002] (Figure 4f) show a large variation in $\mathrm{NO}_{\mathrm{y}}$ values. The model predicts $\mathrm{NO}_{\mathrm{y}}$ values close to the minimum of measured $\mathrm{NO}_{\mathrm{y}}$ mixing ratios (those on the volcanic cloud's southern side). This is probably because box model $\mathrm{NO}_{\mathrm{y}}$ is entirely gas phase whereas the DC-8 $\mathrm{NO}_{\mathrm{y}}$ measurements (Figure 4f) include $\mathrm{NO}_{\mathrm{y}}$ from particles smaller than $1 \mu \mathrm{m}$ diameter. The model cannot include the influence of sub-1 $\mu \mathrm{m}$ diameter particles on $\mathrm{NO}_{\mathrm{y}}$ concentrations as it does not include any particle size distribution information. The largest values of $\mathrm{NO}_{\mathrm{y}}$ are seen on the north side where the number density of small particles is highest. The south side of the volcanic cloud, where the small particles tend to be fewer in number and the particle volume is greater, resembles the box model situation more closely. Here we attempt to use the model to capture the uptake of $\mathrm{NO}_{\mathrm{y}}$ into particles seen in the south volcanic cloud from the flux of $\mathrm{NO}_{\mathrm{y}}$ given to the model at eruption (based on the maximum measured levels). The evolution of gaseous $\mathrm{NO}_{\mathrm{y}}$ with time is shown in Figure 8. We are able to model the minimum values measured by the

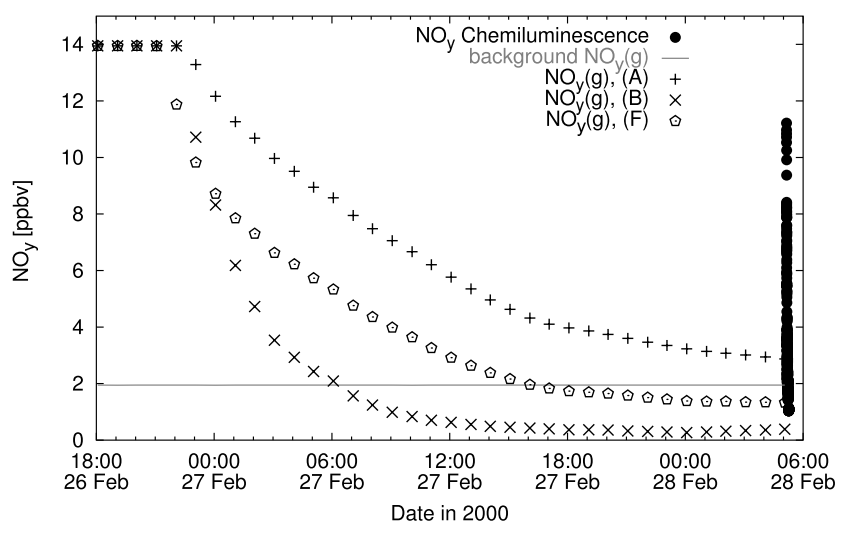

Figure 8. Box model predictions of mixing ratios of inorganic nitrogen along the trajectory in simulations A (pluses), $\mathrm{B}$ (crosses), and $\mathrm{F}$ (open circles) plotted against the stratospheric background $\mathrm{NO}_{\mathrm{y}}$ (line), where $\mathrm{NO}_{\mathrm{y}}=\mathrm{HNO}_{3}+$ $\mathrm{ClONO}_{2}+\mathrm{NO}+\mathrm{NO}_{2}+\mathrm{NO}_{3}+\left(2 * \mathrm{~N}_{2} \mathrm{O}_{5}\right)+\mathrm{HNO}_{4}+$ $\mathrm{BrONO}_{2}$. The range of $\mathrm{NO}_{\mathrm{y}}$ measurements across the plume is also shown (solid circles). 
(a)

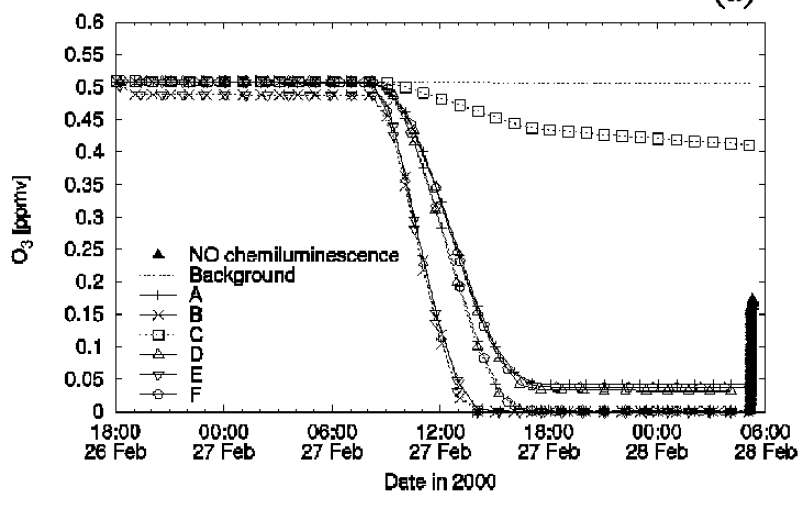

(b)

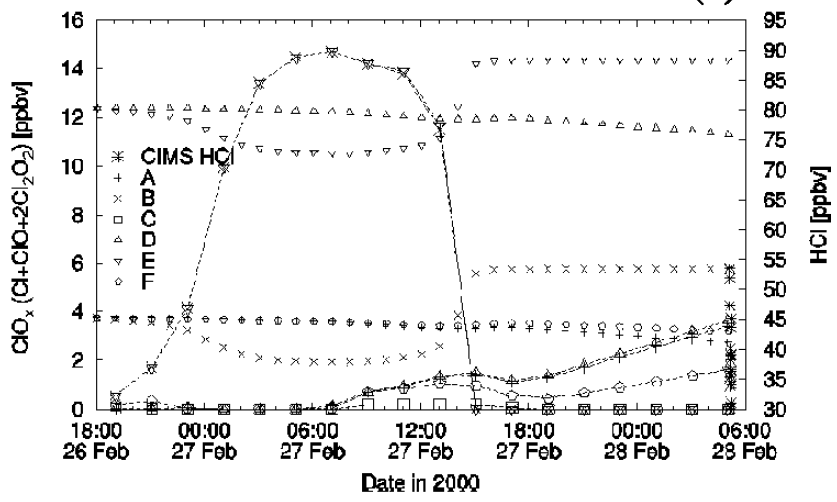

Figure 9. (a) Box model ozone for scenarios A to F, at ambient ECMWF temperatures (solid lines) and with a $2 \mathrm{~K}$ initial cooling (dashed lines). Scenario $\mathrm{C}$ was run with a $6 \mathrm{~K}$ initial cooling. Ozone measurements detailed in Table 1, are also shown $(\sigma)$. (b) Box model $\mathrm{HCl}$ (symbols) and $\mathrm{ClO}_{\mathrm{x}}$ (lines with symbols), separated by emission scenario, as shown in key. Measurements of HCl by CIMS are shown (asterisks).

aircraft, suggesting that the model is broadly capturing the most pronounced $\mathrm{NO}_{\mathrm{y}}$ uptake processes.

[24] Measurements suggest that $\mathrm{HNO}_{3}$ is the dominant $\mathrm{NO}_{\mathrm{y}}$ species within the volcanic cloud; however, the measured nitrogen species are not sufficient to account for all the $\mathrm{NO}_{\mathrm{y}}$ observed. There are limitations concerning the degree to which the model can reproduce the speciation of this 'missing' $\mathrm{NO}_{\mathrm{y}}$, but the rest of the $\mathrm{NO}_{\mathrm{y}}$ is likely to be either $\mathrm{N}_{2} \mathrm{O}_{5}$ or $\mathrm{ClONO}_{2}$ during periods of darkness due to lack of photolysis. $\mathrm{N}_{2} \mathrm{O}_{5}$ is readily absorbed onto ice particles and hydrolyzed to form $\mathrm{HNO}_{3}$, which remains in the solid phase until particle evaporation. Measurements of $\mathrm{ClONO}_{2}$ or $\mathrm{N}_{2} \mathrm{O}_{5}$ would be required to confirm the identity of the missing source of $\mathrm{NO}_{\mathrm{y}}$, although the complete ozone destruction does suggest that it is not in the form of $\mathrm{NO}_{\mathrm{x}}$ on entry to the stratosphere.

\subsubsection{Asymmetry of Concentrations Within the Volcanic Cloud}

[25] As alluded to above the asymmetry of the spatial pattern across the Hekla volcanic cloud for the nitrogen gases (with the highest mixing ratios on the cloud's north side, Figures $4 \mathrm{~b}$ and $4 \mathrm{~d}$ ) can be explained as due to the asymmetry in the characteristics of the particles described in section 4.2. The greater particle volume on the cooler southern side of the volcanic cloud contains a higher proportion of the $\mathrm{HNO}_{3}$ and $\mathrm{NO}_{y}$ meaning that there is less present in the gas phase than on the warmer northern side. This asymmetry could, however, also be due to differing extents of mixing across the volcanic cloud. UK Meteorological analyses show southwesterly winds at 1200 UT on 26-27 February 2000. This might increase mixing into the volcanic cloud on the south side, thereby diluting concentrations of all the constituents of the volcanic cloud. It is certainly true that many of these species such as $\mathrm{HCl}, \mathrm{HF}$ and $\mathrm{SO}_{2}$ show a similar asymmetry to the nitrogen species. Hunton et al. [2005] show that the volcanic cloud measurements shown in Figure 4 for 28 February also look as if they are plotting on a mixing curve between the background atmosphere and highly volcanic cloud-affected air, poten- tially suggesting asymmetric mixing of background air into the volcanic cloud. It is possible that the asymmetry is due to a combination of these factors. The wind direction changed by 1200 UT on the 28 February 2000 to northeasterly, although this was after interception with the DC-8.

\subsection{Observed Reduction in Ozone}

[26] The observed low stratospheric $\mathrm{O}_{3}$ values in the volcanic cloud (minimum $0 \mathrm{ppb}$ ) on the 28 February are suggested not to be a result of entrainment of tropospheric air due to the departure from the usual $\mathrm{O}_{3}-\mathrm{CO}$ mixing curve shown by Hunton et al. [2005]. Assuming (with confidence) that there is no $\mathrm{O}_{3}$ in volcanic emissions, volcanic cloudaffected air will have lower $\mathrm{O}_{3}$ concentrations than the surrounding atmosphere at any altitude (background troposphere $\mathrm{O}_{3}$ levels are $\sim 20 \mathrm{ppb}$ ) due to the dilution of background $\mathrm{O}_{3}$ upon mixing with the volcanic species. However, it seems very unlikely that the volcanic cloud could retain levels of zero $\mathrm{O}_{3}$ by the time that it reached the lower stratosphere, $\sim 34$ hours after emission, without an $\mathrm{O}_{3}$ loss process being active within the volcanic cloud. Stratospheric $\mathrm{O}_{3}$ was initially $0.5 \pm 0.09$ ppm across the trajectory cluster, so any mixing of the volcanic cloud with stratospheric air prior to the measurements makes it further likely that zero $\mathrm{O}_{3}$ concentrations must result from chemical loss brought about in some way from the volcanic emissions as there does not seem to be a satisfactory dynamical reason. 4.4.1. Modeling the Chemical Ozone Destruction

[27] The addition of Hekla sources of halogens (mainly $\mathrm{HCl}$ ) and increased $\mathrm{HNO}_{3}$ and water vapor to the box model reduce ozone concentrations to near zero in all scenarios except $\mathrm{C}$, where ozone is $0.425 \mathrm{ppm}$. The main reactions leading to ozone loss in the model are detailed in Table 4. Model $\mathrm{O}_{3}$ concentrations along the trajectories are shown in Figure 9a.

[28] The return of sunlight to the trajectory at 15 hours (0900 UT) enables the complete destruction of model ozone in scenarios $\mathrm{A}, \mathrm{B}, \mathrm{D}, \mathrm{E}$, and $\mathrm{F}$ (Figure 9a). $\mathrm{O}_{3}$ is not completely destroyed after $35 \mathrm{hrs}$ in scenario $\mathrm{C}$ due to high $\mathrm{NO}_{\mathrm{x}}$ concentrations that quench a large proportion of the 
heterogeneous chlorine activation, resulting in a production of $0.24 \mathrm{ppb} \mathrm{ClO}_{\mathrm{x}}$ (Figure 9b), a modest amount given the available $\mathrm{HCl}$, but still far above background $\mathrm{ClO}_{\mathrm{x}}$ abundances. Additional cooling to ECMWF temperatures had little effect on the concentrations of $\mathrm{HCl}$ and $\mathrm{ClO}_{\mathrm{x}}$ in any of the simulations (not shown), although it did increase the speed of the activation of $\mathrm{HCl}$ by a small amount.

[29] $\mathrm{O}_{3}$ destruction is fastest in scenarios $\mathrm{A}, \mathrm{B}, \mathrm{D}$ E, and $\mathrm{F}$ due to high $\mathrm{ClO}_{\mathrm{x}}$ concentrations of $2-15 \mathrm{ppb}$ (background $\mathrm{ClO}_{\mathrm{x}}$ concentrations were $30 \mathrm{ppt}$ ). $\mathrm{ClO}_{\mathrm{x}}$ enhancements are limited within the model by availability of $\mathrm{ClONO}_{2}$ indicating the dominance of reaction (R1) in Table 4 within the volcanic cloud. Box model calculations suggest that $\mathrm{ClO}$ may reach $15 \mathrm{ppb}$ if the missing $\mathrm{NO}_{\mathrm{y}}$ is $\mathrm{ClONO}_{2}$ (scenario $\mathrm{B}$ ) or $2 \mathrm{ppb}$ if the missing $\mathrm{NO}_{\mathrm{y}}$ is $\mathrm{N}_{2} \mathrm{O}_{5}$ (scenario $\mathrm{A}$ ). Chlorine activation here has been substantially increased by the presence of volcanically induced PSCs due to the additional emissions of $\mathrm{H}_{2} \mathrm{O}$ and $\mathrm{HNO}_{3}$. The University of Colorado Halogen Oxides in the Troposphere instrument detects $\mathrm{ClO}$, OClO, BrO [Thornton et al., 2003, 2005] in situ on the DC-8 and could have detected $\mathrm{ClO}$ in the volcanic cloud; unfortunately, there are no available $\mathrm{ClO}_{\mathrm{x}}$ measurements for this section of the flight (D. Toohey, personal communication, 2005). Direct quantification of the active ozone destruction species $\mathrm{ClO}$ and the nighttime reservoir $\mathrm{OClO}$ might have revealed the source of the missing $\mathrm{NO}_{\mathrm{y}}$.

[30] In summary, box model results indicate that heterogeneous conversion of $\mathrm{HCl}$ to some active form of $\mathrm{Cl}$ is possible within the volcanic cloud due to the presence of volcanically induced PSCs. This is analogous to what occurs in the formation of the ozone hole during polar winters, albeit at a much smaller scale and without the isolation induced by the polar vortex.

\subsubsection{Asymmetry Across the Volcanic Cloud}

[31] We have seen within the box model that reaction (R1) in Table 4 dominates volcanic cloud chemistry if ice and NAT particles are present. If sulfate aerosols dominate, reactions (R3) and (R4) become more important and ozone is still likely to be reduced to $<0.1 \mathrm{ppm}$ although at a slower rate. Given the particle distribution across the cloud (section 4.2), in the absence of dynamical factors we would therefore expect minimum ozone concentrations in the south of the volcanic cloud. However, the overall $\mathrm{O}_{3}$ pattern is asymmetrical across the volcanic cloud, with its concentration being a negative reflection of that shown by $\mathrm{HNO}_{3}$ and $\mathrm{NO}_{\mathrm{y}}$ (Figures $4 \mathrm{e}$ and $4 \mathrm{f}$ ). There is therefore an apparent incongruity in the observation of maximum ozone loss on the north side of the volcanic cloud whilst the most efficient ozone destruction conditions exist on the south side (NAT and ice particles). In truth ozone is likely to be destroyed efficiently throughout the volcanic cloud (due to the presence of at least some NAT throughout the volcanic cloud) but only during the sunlit periods (see reactions (R6)-(R13) in Table 4) of eruption to 1930 UT on 26 February and 0734 to 1830 UT on 27 February. At the time of interception the sampled air had been in darkness for $>10$ hours. We suggest that the asymmetry in the negative ozone anomaly across the volcanic cloud has been caused by the prevailing southerly winds on the 27 February (carrying the volcanic cloud further north), that induce enhanced mixing of nonvolcanic cloud air (which is enriched in ozone) into the south side after the major period of ozone destruction during sunlight. This is supported by the similar asymmetries observed in the concentrations of other gaseous volcanic cloud components (Figures 3 and 4). The north side of the volcanic cloud, however, experiences mixing with air from the south side of the volcanic cloud and to a lesser extent with background air.

[32] Interestingly, because of the temperature gradient along the wind direction, PSCs are trapped geographically to the south side. In other words, movement of the volcanic cloud to warmer temperatures causes the large ice and NAT particles to evaporate and producing gas phase $\mathrm{HNO}_{3}$ enhancements on the north side (see section 4.3).

\subsubsection{Bromine Chemistry}

[33] BrO levels (University of Colorado Halogen Oxides instrument) were at or below the detection limit in the volcanic cloud and did not appear to differ greatly from that outside the volcanic cloud; an upper limit for $\mathrm{BrO}$ in the volcanic cloud is $\sim 15 \mathrm{ppt}$ (detection limit for volcanic cloud encounter duration) (D. Toohey, personal communication, 2006); and a 1 ppb BrO level comparable to those seen in the near-source Soufriere Hills volcano volcanic cloud [Bobrowski et al., 2003] would have been easily detected.

[34] Box model integrations without injection of volcanic halogens into the stratosphere led to no ozone loss even with substantial cooling. Injection of $0.8 \mathrm{ppb} \mathrm{HBr}$ (Table 3) without any $\mathrm{HCl}$ only reduced ozone to $0.25 \mathrm{ppm}$ at ambient temperatures and required a cooling of $3 \mathrm{~K}$ to completely destroy volcanic cloud ozone within the 35 hours. The model $\mathrm{BrO}$ concentrations peaked at $450 \mathrm{ppt}$. By interception with the $\mathrm{DC}-8, \mathrm{BrO}$ concentrations had fallen to $\sim 185 \mathrm{ppt}$ where ozone is still present or below 3 ppt in simulations with a cooling of $3 \mathrm{~K}$ or greater. These lower concentrations result from the conversion of Hekla $\mathrm{BrO}$ back into the $\mathrm{HBr}$ reservoir and are consistent with the $\mathrm{BrO}$ estimate made from observations. Hekla $\mathrm{HBr}$ concentrations are estimated to be an order of magnitude less than $\mathrm{HCl}$; however, bromine remains as active species for longer and so has a greater potential for ozone destruction [e.g., Ko et al., 1998]. Although the modeling study suggests that volcanic cloud ozone loss is likely to be due to the enhancement of stratospheric $\mathrm{HCl}$, it is thus possible that volcanic emissions of $\mathrm{HBr}$ could be equally threatening to stratospheric ozone despite their lower levels.

\subsubsection{Ozone Destruction in Later Volcanic Cloud Encounters}

[35] During later DC-8 encounters with the much diluted volcanic cloud on 5 March and 9 March 2000 (also in darkness; see Hunton et al. [2005] for more details), the halogen oxide instrument found $\mathrm{ClO}_{\mathrm{x}}(\mathrm{OClO}+\mathrm{ClO})$ values of 20-50 ppt in the volcanic clouds. The dominant species is likely $\mathrm{OClO}$ in darkness, as the chlorine chemistry of the diluted volcanic cloud does not appear to be severely altered from the background chlorine chemistry [e.g., Thornton et al., 2005] of this region.

[36] These later volcanic cloud encounters were easily seen in the $\mathrm{ClO}_{\mathrm{x}}$ data, which outside the volcanic clouds averaged $10-15 \mathrm{ppt}$ in darkness at these altitudes [Thornton et al., 2003]; BrO in these later encounters did not appear to differ appreciably from background nighttime values of 0 to a few ppt [see Thornton et al., 2005]. Ozone decreases in the later volcanic cloud encounters were $30-200 \mathrm{ppb}$ in the 
8-12 day old volcanic cloud. Such averaged losses of $\sim 2-$ $25 \mathrm{ppb} \mathrm{d}^{-1}$ of ozone in the volcanic cloud greatly exceed the expected loss rate of $\sim 1.0 \mathrm{ppb} \mathrm{d}^{-1}$ of ozone due to $\mathrm{HO}_{2}$, $\mathrm{ClO}$, and $\mathrm{BrO}$ in the background lowermost Arctic stratosphere [Thornton et al., 2003], and such massive losses cannot be explained by the abundances in the diluted volcanic cloud. Thus it is more plausible that most of the ozone loss observed in the later volcanic cloud encounters occurred via production of rapidly photolyzable chlorine (likely $\mathrm{HOCl}, \mathrm{Cl}_{2}$, etc.; see Table 4) during the first days after the eruption; the ozone loss rates there could have been far higher than the averages derived from later volcanic cloud encounters, as suggested by the model results.

\subsection{Generation of $\mathrm{OH}$ and $\mathrm{HO}_{2}$ in the Hekla Volcanic Cloud}

[37] Elevated levels of $\mathrm{OH}$ and $\mathrm{HO}_{2}$ in the upper atmosphere are usually associated with solar radiation, but in this case there are elevated levels of these species in the volcanic cloud even though it is before sunrise (Figure 5). Gerlach [2004] used calculations of high-temperature gas equilibria to suggest that these radicals may be formed in hot volcanic gas mixtures close to the vent at levels of $\mathrm{ppb}$ to $\mathrm{ppm}$. However, the SOLVE data provide the first direct evidence of $\mathrm{OH}$ elevations within a volcanic cloud. Comparing the estimated levels of $\mathrm{SO}_{2}$ in the magmatic gas mixture (Table 2) and that measured in the 34-hour old plume (Figure 4) suggests that the plume has been diluted by a factor of $\sim 10^{5}$ during transport (assuming negligible $\mathrm{SO}_{2}$ sinks during transport). If the levels of $\mathrm{OH}$ and $\mathrm{HO}_{2}$ observed in the 34-hour old plume (Figure 5) arise purely by dilution of the hot gas mixture present at the vent, the measured levels would suggest levels of $\mathrm{OH}$ and $\mathrm{HO}_{2}$ of orders of ppb to ppm at the vent. These levels are consistent with the levels predicted by the high-temperature modeling of Gerlach [2004]. Such scaling may not be valid, however, because the lifetimes of $\mathrm{HO}_{\mathrm{x}}$ species in the atmosphere are generally very short. In particular, in the volcanic plume $\mathrm{OH}$ will react quickly with the elevated levels of $\mathrm{SO}_{2}, \mathrm{HCl}$ and $\mathrm{CO}$, yielding an $\mathrm{OH}$ lifetime of less than a minute. $\mathrm{HO}_{2}$ reacts quickly with background ozone to form $\mathrm{OH}$ and so has an initial lifetime of less than $10 \mathrm{~min}$. It is unlikely that the high-temperature chemical enhancement near the vent would persist for $\sim 34$ hours and in situ $\mathrm{OH}$ and $\mathrm{HO}_{2}$ production may be present. The elevated levels of $\mathrm{HO}_{\mathrm{x}}$ measured (Figure 5) are not captured by the model and so the mechanism or mechanisms responsible for the observed $\mathrm{HO}_{\mathrm{x}}$ enhancements remain a mystery. Further measurements and modeling of $\mathrm{OH}$ and $\mathrm{HO}_{2}$ near volcanic vents and in plumes as they are transported downwind are to be encouraged in order to better understand these processes. These low levels of $\mathrm{HO}_{\mathrm{x}}$ are not likely to be significantly involved in ozone depletion here due to the presence of much larger concentrations of heterogeneously activated $\mathrm{ClO}_{\mathrm{x}}$ in model results.

\section{Conclusions}

[38] Overall this data set offers much that is new about stratospheric volcanic clouds, especially the point that they may be ice-dominated during their first few days. It is the first time that many gas species have been detected in situ within such a cloud, and it offers a systematic and spatially resolved (i.e., the observed variation in the concentration of many species along the cloud cross section) data set, allowing us to think about processes, reactions and interrelationships between species.

[39] The 1-2 hour long Hekla explosive phase consisted of a tiny fraction of the magma erupted in the 11 hours, but perhaps the majority of the volcanic gas. The 35-hour old Hekla volcanic cloud at $10.4 \mathrm{~km}$ altitude was sharply delineated by three gaseous volcanogenic species, $\mathrm{SO}_{2}$, $\mathrm{HCl}$, and $\mathrm{HF}$, and a much higher number and mass loading of suspended particles. Whereas scrubbing of haloid gases from volcanic clouds by liquid water has been thought to be important in "wet" atmospheric conditions, this scrubbing was not substantially effective in the Hekla case, and haloid gases reached the stratosphere in high proportions. Reflected by its $\mathrm{HO}_{\mathrm{x}}$ content, the volcanic cloud had an oxidizing reactive character that caused some original volcanic gas components $\left(\mathrm{H}_{2} \mathrm{~S}, \mathrm{H}_{2}, \mathrm{CO}\right.$, and perhaps $\mathrm{CH}_{4}$ ) to be completely or partly oxidized after 35 hours.

[40] $\mathrm{HNO}_{3}$ and $\mathrm{NO}_{\mathrm{y}}$ were also notable volcanic cloud components, supporting observations in ground based passive volcanic degassing. Their levels are consistent with production via nitrogen fixation due to volcanic heat or volcanic lightning or a mixture of both these mechanisms. Oxidation of volcanogenic $\mathrm{NH}_{3}$ is also a possible production route. Levels of $\mathrm{NO}_{\mathrm{y}}$ cannot be completely accounted for by the sum of the measured nitrogen species. Without further measurements it is hard to use the model to determine what species might account for this missing $\mathrm{NO}_{\mathrm{y}}$, although in the absence of sunlight $\mathrm{N}_{2} \mathrm{O}_{5}$ and $\mathrm{ClONO}_{2}$ are the most likely species and have been used to initialize the model.

[41] Modeling shows that the explosive emissions of $\mathrm{HNO}_{3}$ and $\mathrm{H}_{2} \mathrm{O}$ induced polar stratospheric cloud particle formation significantly altering the chemistry of the volcanic cloud. The model suggests that 4 types of particles occur within the volcanic cloud once it reaches the stratosphere with ice and nitric acid trihydrate (NAT) accounting for the larger particles (which dominate on the south side of the volcanic cloud) and sulfuric acid tetrahydrate (SAT) and liquid ternary solution $\mathrm{H}_{2} \mathrm{SO}_{4} / \mathrm{H}_{2} \mathrm{O} / \mathrm{HNO}_{3}$ (STS) for the smaller ones (which dominate on the warmer north side of the volcanic cloud). It is likely that fine volcanic ash was present throughout the volcanic cloud.

[42] Ozone is dramatically destroyed inside the volcanic cloud, most probably by heterogeneously activated chlorine from reactions involving volcanically induced cloud particles, especially those on ice and NAT. The chemical model was able to replicate this level of ozone destruction using currently understood stratospheric chemistry. Ozone losses within the volcanic cloud appear to occur at rates far exceeding those of the springtime lower stratosphere ozone losses believed to be largely due to chlorofluorocarbon breakdown products. The key conditions are the elevated $\mathrm{HCl}$ levels in the volcanic cloud and the presence of particle surfaces. $\mathrm{HBr}$ may also play a role. Ozone loss rates of similar magnitude induced by active chlorine species in the lower stratosphere have only been directly observed in the exhaust of solid rockets utilizing ammonium perchlorate oxidizer [e.g., Ross et al., 2000]; the ozone loss rates in the Hekla cloud approach these but over a vastly greater area. 
Paradoxically SAT and STS particles occur in highest abundance where ozone is most depleted (on the volcanic cloud's north side). It is likely that this asymmetry, along with asymmetry in the distribution of other volcanic species, is due to dynamic factors (e.g., enhanced mixing of background stratospheric air into the south side of the volcanic cloud due to the wind field), although in some cases (e.g., $\mathrm{NO}_{\mathrm{y}}$ ) the greater particle volume containing absorbed gaseous species in the southern volcanic cloud may also play a role.

[43] Elevated levels of $\mathrm{OH}$ and $\mathrm{HO}_{2}$ within the nighttime volcanic cloud remain unexplained and are not captured by modeling.

[44] Acknowledgments. For financial support, W.I.R. thanks NSF, T.M. thanks U.K. Natural Environment Research Council (NERC) and the Royal Society, G.M. and T.M. thank the Leverhulme Trust. The British Atmospheric Data Centre is acknowledged for providing access to the UKMO and ECMWF analyses and NERC for computing support within the UK Universities Global Atmospheric Modeling Programme (UGAMP). The authors also thank John Methven for making his trajectory code available and John Pyle and David Pyle for helpful discussions.

\section{References}

Aiuppa, A., C. Federico, A. Franco, G. Giudice, S. Gurrieri, S. Inguaggiato, M. Liuzzo, A. J. S. McGonigle, and M. Valenza (2005a), Emission of bromine and iodine from Mount Etna volcano, Geochem. Geophys. Geosyst., 6, Q08008, doi:10.1029/2005GC000965.

Aiuppa, A., S. Inauaggiato, A. J. S. McGonigle, M. O’Dwyer, C. Oppenheimer, M. J. Padgett, D. Rouwet, and M. Valenza (2005b), $\mathrm{H}_{2}$ S fluxes from Mt Etna, Stromboli and Vulcano (Italy) and implications for the sulfur budget at volcanoes, Geochim. Cosmochim. Acta, 69, 1861-1871.

Al-Saadi, J. A., R. Bradley Pierce, T. D. Fairlie, M. M. Kleb, R. S. Eckman, W. L. Grose, M. Natarajan, and J. R. Olson (2001), Response of middle atmosphere chemistry and dynamics to volcanically elevated sulphate aerosol: Three-dimensional couple model simulations, J. Geophys. Res., 106, 27,255-27,275.

Arason, P. (2005), Lightning during volcanic eruptions in Iceland, Geophys. Res. Abstr., 7, 05369.

Ballenthin, J. O., W. F. Thorn, T. M. Miller, A. A. Viggiano, D. E. Hunton, M. Koike, Y. Kondo, N. Takegawa, H. Irie, and H. Ikeda (2003), In situ $\mathrm{HNO}_{3}$ to $\mathrm{NO}_{y}$ instrument comparison during SOLVE, J. Geophys. Res., 108(D6), 4188, doi:10.1029/2002JD002136.

Bandy, A. R., P. J. Maroulis, L. A. Wilner, and A. L. Torres (1982), Estimates of the fluxes of $\mathrm{NO}, \mathrm{SO}_{2}, \mathrm{H}_{2} \mathrm{~S}, \mathrm{CS}_{2}$ and OCS from Mt. St. Helens deduced from in situ plume concentration measurements, Geophys. Res. Lett., 9, 1097-1100.

Bekki, S. (1995), Oxidation of volcanic $\mathrm{SO}_{2}$ : A sink for stratospheric $\mathrm{OH}$ and $\mathrm{H}_{2} \mathrm{O}$, Geophys. Res. Lett., 22, 913-916.

Bekki, S., and J. A. Pyle (1994), A two-dimensional modelling study of the volcanic eruption of Mount Pinatubo, J. Geophys. Res., 99, 18,86118,869 .

Bekki, S., J. A. Pyle, W. Zhong, R. Toumi, J. D. Haigh, and D. M. Pyle (1996), The role of microphysical and chemical processes in prolonging the climate forcing of the Toba eruption, Geophys. Res. Lett., 23, 26692672.

Bobrowski, N., G. Hönninger, B. Galle, and U. Platt (2003), Detection of bromine monoxide in a volcanic plume, Nature, 423, 273-274.

Brune, W. H., P. S. Stevens, and J. H. Mather (1995), Measuring OH and $\mathrm{HO}_{2}$ in the troposphere by laser-induced fluorescence at low pressure, J. Atmos. Sci., 52, 3328-3336.

Bureau, H., H. Keppler, and N. Métrich (2000), Volcanic degassing of bromine and iodine: Experimental fluid/melt partitioning data and applications to stratospheric chemistry, Earth Planet. Sci. Lett., 183, 51-60.

Cape, J. N., J. Methven, and L. E. Hudson (2000), The use of trajectory cluster analysis to interpret trace gas measurements at Mace Head Ireland, Atmos. Environ., 34, 3651-3663.

Carslaw, K. S., and S. L. Clegg (1997), Modeling the composition of liquid stratospheric aerosols, Rev. Geophys., 35, 125-154.

Carslaw, K. S., B. Luo, and T. Peter (1995), An analytic expression for the composition of aqueous $\mathrm{HNO}_{3}-\mathrm{H}_{2} \mathrm{SO}_{4}$ stratospheric aerosols including gas phase removal of $\mathrm{HNO}_{3}$, Geophys. Res. Lett., 22, 1877-1880.

Carslaw, K. S., J. A. Kettleborough, M. J. Northway, S. Davies, R.-S. Gao, D. W. Fahey, D. G. Baumgardner, M. P. Chipperfield, and A. Kleinböhl (2002), A vortex-scale simulation of the growth and sedimentation of large nitric acid hydrate particles, J. Geophys. Res., 107(D20), 8300, doi:10.1029/2001JD000467.

Chipperfield, M. P. (1999), Multiannual simulations with a three-dimensional chemical transport model, J. Geophys. Res., 104, 1781-1805.

Chipperfield, M. P., E. R. Lutman, J. A. Kettleborough, and J. A. Pyle (1997), Model studies of the chlorine deactivation and formation of the $\mathrm{ClONO}_{2}$ collar in the Arctic polar vortex, J. Geophys. Res., 102, $1467-1478$.

Delmelle, P. (2003), Environmental impacts of tropospheric volcanic gas plumes, in Volcanic Degassing, edited by C. Oppenheimer, D. M. Pyle, and J. Barclay, Geol. Soc. Spec. Publ., 213, 381-399.

Gerlach, T. M. (2004), Volcanic sources of tropospheric ozone-depleting trace gases, Geochem. Geophys. Geosyst., 5, Q09007, doi:10.1029/ 2004 GC000747.

Graedel, T. (1977), The homogeneous chemistry of atmospheric sulfur, Rev. Geophys., 15, 421-428.

Guirlet, M., M. P. Chipperfield, J. A. Pyle, F. Goutail, J. P. Pommereau, and E. Kyro (2000), Modeled Arctic ozone depletion in winter 1997/1998 and comparison with previous winters, J. Geophys. Res., 105, 22,18522,200 .

Hallar, A. G., L. M. Avallone, R. L. Herman, B. E. Anderson, and A. J. Heymsfield (2004), Measurements of ice water content in tropopause region Arctic cirrus during the SAGE III Ozone Loss and Validation Experiment (SOLVE), J. Geophys. Res., 109, D17203, doi:10.1029/ 2003JD004348.

Hanson, D., and K. Mauersberger (1988), Laboratory studies of the nitric acid triydrate: implications for the South polar stratosphere, Geophys. Res. Lett., 15, 855-858.

Haraldsson, K. O., S. G. Arnason, G. Larsen, and J. Eiriksson (2002), The Hekla eruption of 2000: The tephra fall, paper presented at 25th Nordic Geological Winter Meeting, Geosci. Soc. of Iceland, Reykjavik.

Hobbs, P. V., J. P. Tuell, D. A. Hegg, L. F. Radke, and M. K. Eltgroth (1982), Particles and gases in the emissions from the 1980-1981 volcanic eruptions of Mount St. Helens, J. Geophys. Res., 87, 11,062-11,086.

Hobbs, P. V., L. F. Radke, J. H. Lyons, R. J. Ferek, D. J. Coffman, and T. J. Casadevall (1991), Airborne measurements of particles and gas emissions from the 1990 volcanic eruptions of Mount Redoubt, J. Geophys. Res., 96, 18,735-18,752.

Horrocks, L. A., C. Oppenheimer, M. R. Burton, and H. J. Duffell (2003), Compositional variation in tropospheric volcanic gas plumes: Evidence from ground-based remote sensing, in Volcanic Degassing, edited by C. Oppenheimer, D. M. Pyle, and J. Barclay, Geol. Soc. Spec. Publ., 213, 349-369.

Horwell, C. J., R. S. J. Sparks, T. S. Brewer, E. W. Llewellin, and B. J. Williamson (2003), The characterisation of respirable volcanic ash from the Soufriere Hills Volcano, Montserrat, with implications for health hazard, Bull. Volcanol., 65, 346-362.

Huebert, B., P. Vitousek, J. Sutton, T. Elias, J. Heath, S. Coeppicus, S. Howell, and B. Blomquist (1999), Volcano fixes nitrogen into plant available forms, Biogeochemistry, 47, 111-118.

Hunton, D. E., et al. (2005), In-situ aircraft observations of the 2000 Mt. Hekla volcanic cloud: Composition and chemical evolution in the Arctic lower stratosphere, J. Volcanol. Geotherm. Res., 145, 23-34.

Ko, M. K. W., N. Dak Sze, C. Scott, J. M. Rodriguez, D. K. Weinstein, and S. P. Sander (1998), Ozone depletion potential of $\mathrm{CH}_{3} \mathrm{Br}, J$. Geophys. Res., 103, 28,187-28,195.

Koike, M., et al. (2002), Redistribution of reactive nitrogen in the Arctic lower stratosphere in the 1999/2000 winter, J. Geophys. Res., 107(D2), 8275, doi:10.1029/2001JD001089.

Koop, T., K. S. Carslaw, and T. Peter (1997), Thermodynamic stability and phase transitions of PSC particles, Geophys. Res. Lett., 24, 2199-2202.

Lacasse, C., S. Karlsdóttir, G. Larsen, H. Soosalu, W. I. Rose, and G. G. J. Ernst (2003), Weather radar observations of the Hekla 2000 eruption cloud, Iceland, Bull. Volcanol., 66, 457-473.

Lee, D. S., I. Köhler, E. Grobler, F. Rohrer, R. Sausen, L. Gallardo-Klenner, J. G. J. Olivier, F. J. Dentener, and A. F. Bouwman (1997), Estimations of global $\mathrm{NO}_{\mathrm{x}}$ emissions and their uncertainties, Atmos. Environ., 31, 1735-1749.

Logan, J. A. (1983), Nitrogen oxides in the troposphere: Global and regional budgets, J. Geophys. Res., 88, 10,785-10,807.

Mather, T. A., A. G. Allen, B. M. Davison, D. M. Pyle, C. Oppenheimer, and A. J. S. McGonigle (2004a), Nitric acid from volcanoes, Earth Planet. Sci. Lett., 218, 17-30.

Mather, T. A., D. M. Pyle, and A. G. Allen (2004b), Volcanic source for fixed nitrogen in Earth's early atmosphere, Geology, 32, 905-908.

May, R. D. (1998), Open-path, near-infrared tunable diode laser spectrometer for atmospheric measurements of $\mathrm{H}_{2} \mathrm{O}$, J. Geophys. Res., 103, $19,161-19,172$.

Methven, J. (1997), Offline trajectories calculation and accuracy, Tech. Rep. 44, UGAMP, UK Univ. Global Atmos. Modell. Programme, Reading, U. K. 
Moune, S., P.-J. Gauthier, S. R. Gislason, and O. Sigmarssson (2006), Trace element degassing and enrichment in the eruptive plume of the 2000 eruption of Hekla volcano, Iceland, Geochim. Cosmochim. Acta, 70, $461-479$.

Navarro-González, R., M. J. Molina, and L. T. Molina (1998), Nitrogen fixation by volcanic lightning in the early Earth, Geophys. Res. Lett., 25 3123-3126.

Newman, P. A., et al. (2002), An overview of the SOLVE/THESEO 2000 campaign, J. Geophys. Res., 107(D20), 8259, doi:10.1029/ 2001JD001303.

Oskarsson, N. (1980), The interaction between volcanic gases and tephra: Fluorine adhering to tephra of the 1970 Hekla eruption, J. Volcanol. Geotherm. Res., 8, 251-266.

Oskarsson, N. (1981), The chemistry of Icelandic lava incrustations and the latest stages of degassing, J. Volcanol. Geotherm. Res., 10, 93-111.

Robinson, A. D., et al. (2005), Ozone loss derived from balloon-borne tracer measurements in the 1999/2000 Arctic winter, Atmos. Chem. Phys., 5, 1423-1436.

Rose, W. I., et al. (2003), The February-March 2000 Eruption of Hekla, Iceland from a Satellite Perspective, in Volcanism and Earth's Atmosphere, Geophys. Monogr. Ser., vol. 139 edited by A. Robock and C. Oppenheimer, pp. 107-132. AGU, Washington, D. C.

Ross, D. E. M., J. A. Pyle, N. R. P. Harris, J. D. McIntyre, G. A. Millard, A. D. Robinson, and R. Busen (2004), Investigation of Arctic ozone depletion sampled over midlatitudes during the Egrett campaign of spring/summer 2000, Atmos. Chem. Phys., 4, 1407-1417.

Ross, M. N., et al. (2000), Observation of stratospheric ozone depletion associated with Delta II rocket emissions, Geophys. Res. Lett., 27, 22092212.

Rozanov, E. V., M. E. Schlesinger, N. G. Andronova, F. Yang, S. L. Malyshev, V. A. Zubov, T. A. Egorova, and B. Li (2002), Climate/ chemistry effects of the Pinatubo volcanic eruption simulated by the UIUC stratosphere/troposphere GCM with interactive photochemistry, J. Geophys. Res., 107(D21), 4594, doi:10.1029/2001JD000974.

Sander, S. P., et al. (2003), Chemical kinetics and photochemical data for use in atmospheric studies, in Evaluation Number 14, JPL Publ., 02-25. (Available at http://jpldataeval.jpl.nasa.gov).

Sharma, K., S. Blake, S. Self, and A. J. Krueger (2004), $\mathrm{SO}_{2}$ emissions from basaltic eruptions, and the excess sulfur issue, Geophys. Res. Lett., 31, L13612, doi:10.1029/2004GL019688.

Sinnhuber, B. M., et al. (2000), Large loss of total ozone during the Arctic winter of 1999/2000, Geophys. Res. Lett., 27, 3473-3476.

Sparks, R. S. J., M. Bursik, S. Carey, J. Gilbert, L. Glaze, H. Sigurdsson, and A. Woods (1997), Volcanic Plumes, 574 pp., John Wiley, Hoboken, N. J.

Symonds, R. B., W. I. Rose, and M. H. Reed (1988), Contribution of $\mathrm{Cl}$ - and F-bearing gases to the atmosphere by volcanoes, Nature, 334, 415-418.

Symonds, R. B., W. I. Rose, G. J. S. Bluth, and T. M. Gerlach (1994), Volcanic gas studies: Methods, results and applications, in Volatiles in
Magmas, Rev. Mineral., vol. 30, edited by M R. Carroll and J. R. Hollaway, pp. 1-66, Mineral. Soc. of Am., Washington, D. C.

Tabazadeh, A., and R. P. Turco (1993), Stratospheric chlorine injection by volcanic eruptions: $\mathrm{HCl}$ scavenging and implications for ozone, Science, 260, $1082-1086$.

Textor, C., Hans-F. Graf, M. Herzog, and J. M. Oberhuber (2003), Injection of gases into the stratosphere by explosive volcanic eruptions, J. Geophys. Res., 108(D19), 4606, doi:10.1029/2002JD002987.

Textor, C., H.-F. Graf, C. Timmreck, and A. Robock (2004), Emissions from volcanoes, in Emissions of Chemical Compounds in the Atmosphere, Adv. Global Change Res., vol. 18, edited by C. Granier, C. Reeves, and P. Artaxo. pp. 269-303, Springer, New York.

Thornton, B. F., D. W. Toohey, L. M. Avallone, H. Harder, M. Martinez, J. B. Simpas, W. H. Brune, and M. A. Avery (2003), In situ observations of $\mathrm{ClO}$ near the winter polar tropopause, J. Geophys. Res., 108(D8), 8333, doi:10.1029/2002JD002839.

Thornton, B. F., et al. (2005), Variability of active chlorine in the lowermost Arctic stratosphere, J. Geophys. Res., 110, D22304, doi:10.1029/ 2004JD005580.

Tie, X., et al. (2003), Effect of sulfate aerosol on tropospheric $\mathrm{NO}_{x}$ and ozone budgets: Model simulations and TOPSE evidence, J. Geophys. Res., 108(D4), 8364, doi:10.1029/2001JD001508.

Turco, R. P., R. C. Whitten, and O. B. Toon (1982), Stratospheric aerosols: Observation and theory, Rev. Geophys., 20, 233-279.

Wallace, P. J., S. Carn, W. Rose, and T. Gerlach (2003), Integrating petrologic and remote sensing perspectives on magmatic volatiles and volcanic degassing, Eos Trans. AGU, 84, 446-447.

Zreda-Gostynska, G., P. R. Kyle, D. Finnegan, and K. M. Prestbo (1997), Volcanic gas emissions from Mount Erubus and their impact on the Antarctic environment, J. Geophys. Res., 102, 15,039-15,055.

B. Anderson, NASA Langley Research Center, M/S 483, Hampton, VA 23681, USA.

J. O. Ballenthin, D. E. Hunton, T. M. Miller, and A. A. Viggiano, Air Force Research Laboratory, Hanscom AFB, MA 01731, USA.

T. M. Gerlach, USGS Cascades Volcano Observatory, Vancouver, WA 98683, USA.

Y. Kondo, Research Center for Advanced Science and Technology, University of Tokyo, 4-6-1 Komaba, Meguro, Tokyo 153-8904, Japan.

T. A. Mather, Department of Earth Sciences, University of Oxford, Parks Road, Oxford OX1 3PR, UK.

G. A. Millard, Department of Earth Sciences, University of Cambridge, Downing Street, Cambridge CB2 3EQ, UK.

C. Oppenheimer, Department of Geography, University of Cambridge, Downing Place, Cambridge CB2 3EN, UK.

W. I. Rose, Geological Engineering and Sciences, Michigan Technological University, Houghton, MI 49931, USA. (raman@mtu.edu)

B. F. Thornton, Program in Atmospheric and Oceanic Sciences, University of Colorado, Campus Box 311, Boulder, CO 80309, USA. 